\title{
Air quality modeling for Warsaw agglomeration
}

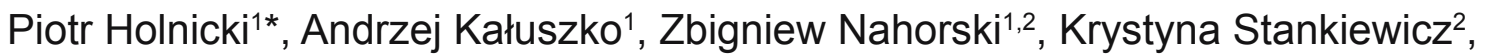 \\ Wojciech Trapp ${ }^{3}$
}

\author{
${ }^{1}$ Systems Research Institute, Polish Academy of Sciences, Poland \\ ${ }^{2}$ Warsaw School of Information Technology, Poland \\ ${ }^{3}$ EKOMETRIA, Office of the Studies \& Ecological Measurements, Poland \\ *Corresponding author's e-mail: holnicki@ibspan.waw.pl
}

Keywords: urban air pollution, emission inventory, air quality standards, source apportionment.

\begin{abstract}
The paper investigates the air quality in the urban area of Warsaw, Poland. Calculations are carried out using the emissions and meteorological data from the year 2012. The modeling tool is the regional CALMET/CALPUFF system, which is used to link the emission sources with the distributions of the annual mean concentrations. Several types of polluting species that characterize the urban atmospheric environment, like $\mathrm{PM}_{10}$, $\mathrm{PM}_{2.5}, \mathrm{NOx}, \mathrm{SO}_{2}, \mathrm{~Pb}, \mathrm{~B}(\mathrm{a}) \mathrm{P}$, are included in the analysis. The goal of the analysis is to identify the most polluted districts and polluting compounds there, to check where the concentration limits of particular pollutants are exceeded. Then, emission sources (or emission categories) which are mainly responsible for violation of air quality standards and increase the adverse health effects, are identified. The modeling results show how the major emission sources - the energy sector, industry, traffic and the municipal sector - relate to the concentrations calculated in receptor points, including the contribution of the transboundary inflow. The results allow to identify districts where the concentration limits are exceeded and action plans are needed. A quantitative source apportionment shows the emission sources which are mainly responsible for the violation of air quality standards. It is shown that the road transport and the municipal sector are the emission classes which substantially affect air quality in Warsaw. Also transboundary inflow contributes highly to concentrations of some pollutants. The results presented can be of use in analyzing emission reduction policies for the city, as a part of an integrated modeling system.
\end{abstract}

\section{Introduction}

The problem related to urban air pollution figures prominently in atmospheric environmental concern. Cities and agglomerations are highly susceptible to air pollution due to high concentration of different human activities and related emissions. The European scale studies developed the City Delta approach (Thunis et al. 2007) to identify and quantify the systematic differences (deltas) between urban and rural background air quality.

Warsaw, similarly as many other European agglomerations (Lim et al. 2005, Calori et al. 2006, Mediavilla-Sahagún and ApSimon 2006, Buchholz et al. 2013), has recently suffered from high concentrations of some air pollutants which characterize the urban atmospheric environment. These are usually particulate matter, sulfur- and nitrogen oxides, carbon monoxide, some heavy metals, as well as polycyclic aromatic hydrocarbons in some cases. In practice, the adverse impact of some particular pollutants on urban air quality depends on several individual factors, such as the city location, topography, the structure of the emission field, meteorology, etc. In Warsaw, the composition of the main polluting species, their spatial distribution and their maximum values also reflect the peculiar structure of the local emission field, which is determined by two dominating factors.

The first one, of more general character, relates to coal, which is the main fossil fuel used in Poland for power generation and for heating in the residential sector. The district heating system operates in the main part of Warsaw, but in the peripheral districts and the neighboring rural area coal fired small scale heating installations are used, which considerably contribute to worsening of air quality. This category of emission sources is responsible for particulate matter pollution (especially $\mathrm{PM}_{2.5}$ ), $\mathrm{SO}_{2}$, some heavy metals and $\mathrm{B}(\mathrm{a}) \mathrm{P}$ (RogulaKozłowska et al. 2013). The highly toxic B(a)P pollution, originating from the municipal sector, is apparent in Warsaw and constitutes a serious general problem in Poland (EEA 2012).

The second dominating pollution category relates to traffic-induced emission, due to the steadily increasing number of cars registered in Warsaw. Their number went up by $80 \%$ in the last decade (//wawalove.pl/Ile-samochodow-jezdzi-poWarszawie-a12684), which contrasts with very different trends in many other European cities. Traffic originated emission is mainly responsible for $\mathrm{NO}_{\mathrm{x}}, \mathrm{Pb}, \mathrm{CO}, \mathrm{C}_{6} \mathrm{H}_{6}$ concentrations, but it also contributes to $\mathrm{PM}_{10}$ pollutions via the re-suspended 
particles (Dimitriou and Kassomenos 2014, Kiesewetter et al. 2014). In particular, concentrations of $\mathrm{NO}_{\mathrm{X}}$ and $\mathrm{PM}_{10}$ have been on the increase.

An important part of the resulting air pollution in Warsaw is the transboundary inflow of some pollutants coming from distant sources.

Many of the earlier urban scale modeling studies have addressed the road transport originated pollutants. Berkowicz et al. (2003) present modeling results of the traffic related NOx and CO pollution in Copenhagen. They consider the vehicle emission factor with differentiation between vehicle types (passenger cars, vans, trucks, buses, etc.), fuel used, engine capacity, emission legislation category. The same pollutants are considered by Buchholz et al. (2013) for Luxembourg. In the emission scenarios for the years 1998-2006, they consider only the most important sources, i.e. the road transport and nonindustrial combustion. A Gaussian dispersion model is used in simulation. An integrated analysis concerning $\mathrm{NO}_{2}$ and $\mathrm{CO}$ concentration in the Turin agglomeration is presented in Calori et al. (2006). The Lagrangian particle model is applied to the simulation of emission and meteorological scenarios. The results obtained provide a reference point for discussion of possible improvements. The impact of the road transport on the urban air quality in London is discussed in Oxley et al. (2009). In this case, $\mathrm{NO}_{2}, \mathrm{NOx}$ and $\mathrm{PM}_{10}$ are considered as the main traffic-related pollutants. Integrated modeling assessment is applied to link emissions, pollution concentrations, human exposure and the possible emission abatement techniques. London air pollution is also discussed by Mediavilla-Shagún and ApSimon (2006), who consider integrated analysis of $\mathrm{PM}_{10}$ pollution. The aim of the study is to provide a tool to assess and select the most effective emission reduction scenarios.

Spatial and temporal patterns of air pollution are also studied. Dimitriou and Kassomenos (2014) apply a linear regression model to reconstruct daily $\mathrm{PM}_{10}$ and $\mathrm{PM}_{2.5}$ concentrations in Paris. They consider four central and eleven surrounding districts as emission sources affecting urban air quality. Patton et al. (2014) discuss the spatial and temporal patterns in traffic-related concentrations of $\mathrm{NO}_{2}, \mathrm{NOx}, \mathrm{PM}_{2.5}$, and $\mathrm{CO}$ near the main roads in Boston. In Poland air quality modeling studies for Mazovian Voivodship, containing Warsaw as the main agglomeration, have been performed by Trapp (2010). The gaseous and particulate matter pollutions are considered.

\section{Warsaw case study implementation}

\section{The study area and spatial resolution}

To simulate pollutant dispersion processes we apply the Gaussian puff model CALPUFF v.5 (Scire et al. 2000). Meteorological fields are generated by the CALMET cooperating preprocessor, taking into account, among other factors, the impact of terrain topography, orography and aerodynamic roughness of the ground. The aim of simulation is to obtain the spatial maps of year average concentrations of the main urban pollutants, to show districts/areas where the pollution limits are exceeded and to identify emission sources responsible for these violations. The results, including the earlier uncertainty estimates and model validation (Holnicki and Nahorski 2015, Holnicki et al. 2016), may be useful in formulation of the respective regulatory actions and emission reduction strategy (compare e.g. Carnevale et al. 2012, Lim et al. 2005, Mediavilla-Sahagún and ApSimon 2006, Pisoni et al. 2010).

The air quality analysis presented below deals with the primary and secondary polluting compounds, which are characteristic for the urban atmospheric environment, including transboundary pollution inflow from distant sources. The main polluting compounds, discussed in this study, are shown in Table 1.

Table 1. Air pollutants considered (primary and secondary)

\begin{tabular}{|l|l|}
\hline \multicolumn{1}{|c|}{ Emission / primary pollutants } & \multicolumn{1}{c|}{ Secondary pollutants / particulate matter } \\
\hline $\mathrm{SO}_{2}$ - sulfur dioxide & $\mathrm{SO}_{4}^{=}-$sulfate aerosol \\
\hline $\mathrm{NO}_{\mathbf{X}}-$ nitrogen oxides & $\mathrm{NO}_{3}^{-}-$nitrate aerosol \\
\hline & $\mathrm{HNO}_{3}-$ nitric acid \\
\hline $\mathrm{PPM}_{10}-$ primary PM, $\Phi \leq 10 \mu \mathrm{m}$ & \\
\hline $\mathrm{PPM}_{10-R}-$ re-suspended PPM10 & $\mathrm{PM}_{10}=\mathrm{PPM}_{10}+\mathrm{PPM}_{10-\mathrm{R}^{-}}+\mathrm{SO}_{4}^{=}+\mathrm{NO}_{3}^{-}$ \\
\hline $\mathrm{PPM}_{2.5}-$ primary PM, $\Phi \leq 2.5 \mu \mathrm{m}$ & \\
\hline $\mathrm{PPM}_{2.5-\mathrm{R}}-$ re-suspended PPM2.5 & $\mathrm{PM}_{2.5}=\mathrm{PPM}_{2.5}+\mathrm{PPM}_{2.5-\mathrm{R}^{-}}+\mathrm{SO}_{4}^{=}+\mathrm{NO}_{3}^{-}$ \\
\hline $\mathrm{CO}-$ carbon monoxide & \\
\hline $\mathrm{C}_{6} \mathrm{H}_{6}-$ benzene & \\
\hline $\mathrm{NH} H_{3}-$ ammonia & \\
\hline $\mathrm{BaP}-$ benzo(a)pyrene & \\
\hline $\mathrm{Ni}-$ nickel & \\
\hline $\mathrm{Cd}-$ cadmium & \\
\hline $\mathrm{Pb}-$ lead & \\
\hline $\mathrm{As}-$ arsenic & \\
\hline $\mathrm{Hg}-$ mercury & \\
\hline
\end{tabular}


The numerical simulation is based on the emission and meteorological dataset for the year 2012. The annual mean concentrations of the pollutants listed in Table 1 were evaluated and compared with the EU and national norms (CAFE 2008, ME 2012). Accuracy of calculation was assessed. The Warsaw metropolitan area (about $520 \mathrm{~km}^{2}$ within the administrative borders), shown in Fig. 1, is discretized for the computational reasons using the homogeneous grid $0.5 \mathrm{~km} \times 0.5 \mathrm{~km}$.

CALLPUFF is a new generation Gaussian puff model (Scire et al.2000, Trapp 2010), which operates in the Lagrangian system of coordinates and considers the geophysical data and the temporal and spatial variability of meteorological conditions in three dimensions. It is a multilayer, non-stationary model designed for calculating concentrations of many substances, emitted by different types of sources. Chemical and physical transformations of pollutants are considered.

CALPUFF/CALMET modelling system has been used in a number of studies to investigate gaseous (Elbir 2003, Holnicki and Nahorski 2013) and particulate matter (Villasenor et al. 2003, Huber et al. 2004, Trapp 2010, Tartakovsky et al. 2013, ETC/ACM 2013) pollutants dispersions, both in the regional and urban scale. Validation studies (Oshan et al. 2006, Dresser and Huizer 2011) showed a satisfactory agreement with the observations, especially for annual mean concentrations. This is also achieved in our study (see the model performance estimates presented in Section 4). On the other hand, Holmes and Morawska (2006) and Brode (2012) state that the model is not recommended to analyze the near field and short-term episodes. This fact is confirmed by CALPUFF validation results presented in (Holnicki et al. 2016), which are also based on the Warsaw case study.

The concentrations are computed at 2248 fictitious receptor points, which are located in the centers of the basic grid elements shown in Fig. 1. The same spatial resolution applies to the local, spatial and line emission sources, located inside the administrative borders. The local emission field is wider than the receptor area - the sources located in the outskirt of Warsaw, but inside the circle of the diameter about $90 \mathrm{~km}$ (shown as the bottom corner icon in Fig. 1) are also included in the emission field, but the variable spatial resolution is used in this case. Two exemplary receptors marked gray in Fig. 1 - \#658 (residential area) and \#1217 (crossroad) - are used in Section 3 to illustrate the relation between a source apportionment and a receptor's location. The figure also shows the locations of monitoring stations. Observations taken at these stations were utilized in the assessment of the model performance (see Section 4).

\section{Emission dataset}

The main activities influencing the Warsaw air quality are: road transport, residential heating, power generation, and industry. In addition to the activity rates in the above sectors, technology emission parameters were collected. The aggregated emissions from the basic sectors in Warsaw agglomeration in the year 2012 are presented in Table 2 below, based on (WIOS 2012). The table shows the emission volumes of the main pollutants and the share of each sector in the total emission.

Emission field in an urban area usually represents concentration of a large number of sources in the study domain, which vary in technological parameters, emission characteristics, composition of emitted compounds, and also the assigned uncertainty (Holnicki and Nahorski 2015). To take into account specific technological characteristics of the different emission sources, the total emission field was split down into the following categories: point (high/low), area, and line (mobile) sources. A separate class of the high point sources was distinguished to take account of specific technological

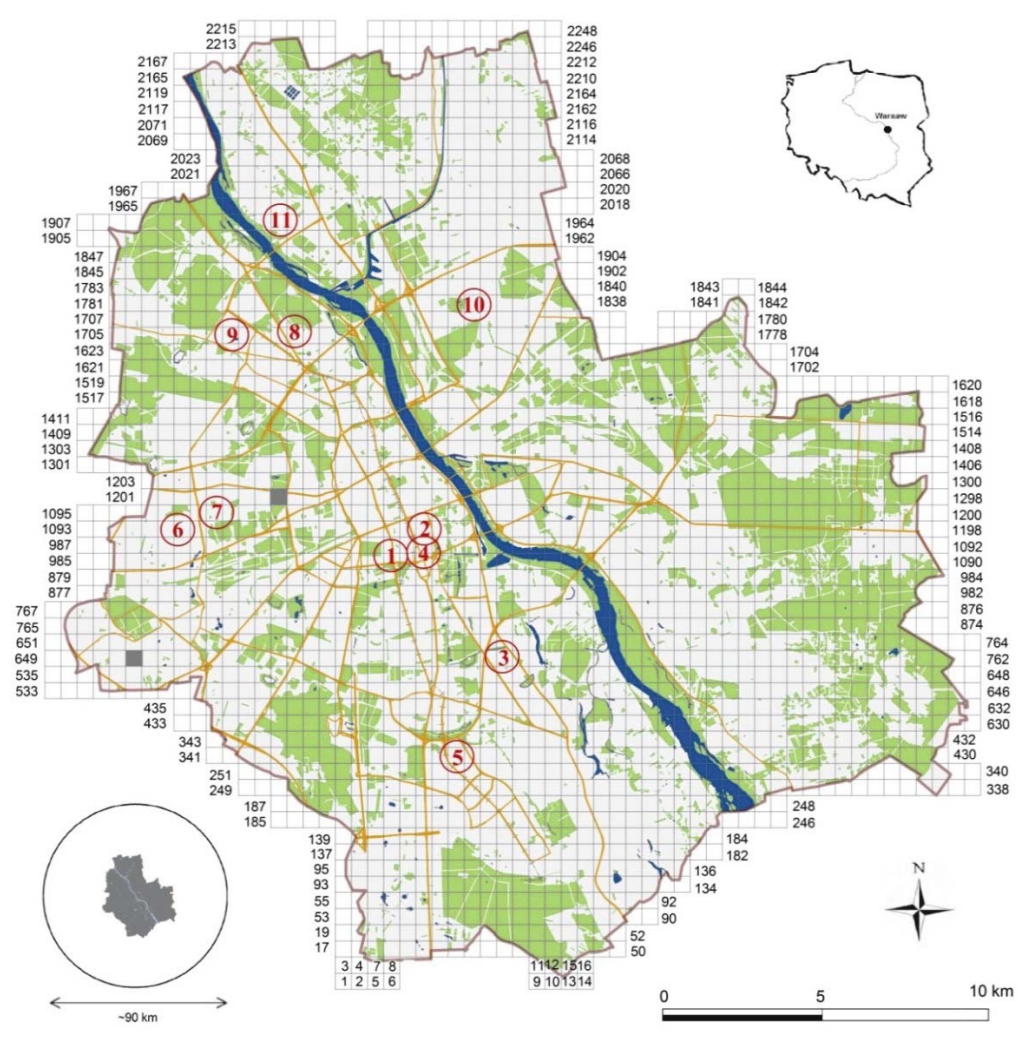

Fig. 1. The Warsaw area - locations of the receptor points and the monitoring stations 
Table 2. Emission volumes by sector in Warsaw agglomeration in the year 2012 (Holnicki et al. 2016)

\begin{tabular}{|l|r|r|r|r|r|r|r|r|r|r|c|c|}
\hline \multirow{2}{*}{ Sector } & \multicolumn{2}{|c|}{$\mathrm{SO}_{2}$} & \multicolumn{2}{c|}{$\mathrm{NOx}$} & \multicolumn{2}{c|}{$\mathrm{PM}_{10}$} & \multicolumn{2}{c|}{$\mathrm{PM}_{2.5}$} & \multicolumn{2}{c|}{$\mathrm{CO}$} & \multicolumn{2}{c|}{$\mathrm{C}_{6} \mathrm{H}_{6}$} \\
\cline { 2 - 15 } & \multicolumn{1}{|c|}{$[\mathrm{Mg}]$} & {$[\%]$} & \multicolumn{1}{c|}{$[\mathrm{Mg}]$} & {$[\%]$} & {$[\mathrm{Mg}]$} & {$[\%]$} & {$[\mathrm{Mg}]$} & {$[\%]$} & {$[\mathrm{Mg}]$} & {$[\%]$} & {$[\mathrm{Mg}]$} & {$[\%]$} \\
\hline Energy/industry & 12478 & 87.6 & 7781 & 40.0 & 803 & 10.5 & 264 & 8.8 & 2504 & 7.5 & - & - \\
\hline Residential & 931 & 6.5 & 614 & 3.2 & 2105 & 27.4 & 1603 & 53.3 & 8830 & 26.5 & 0.075 & 0.0 \\
\hline Transport & 837 & 5.9 & 11051 & 56.8 & 4772 & 62.1 & 1141 & 37.9 & 21955 & 66.0 & 317.4 & 100.0 \\
\hline Total & 14246 & 100 & 19446 & 100 & 7680 & 100 & 3008 & 100 & 33289 & 100 & 317.5 & 100 \\
\hline
\end{tabular}

Table 2 (continued). Emission volumes by sector in Warsaw agglomeration in the year 2012

\begin{tabular}{|l|r|r|r|r|r|r|r|r|r|r|}
\hline \multirow{2}{*}{ Sector } & \multicolumn{2}{|c|}{ As } & \multicolumn{2}{c|}{ Cd } & \multicolumn{2}{c|}{$\mathrm{Ni}$} & \multicolumn{2}{c|}{$\mathrm{Pb}$} & \multicolumn{2}{c|}{$\mathrm{BaP}$} \\
\cline { 2 - 11 } & \multicolumn{1}{|c|}{$[\mathrm{kg}]$} & {$[\%]$} & \multicolumn{1}{c|}{$[\mathrm{kg}]$} & {$[\%]$} & \multicolumn{1}{c|}{$[\mathrm{kg}]$} & \multicolumn{1}{c|}{$[\%]$} & {$[\mathrm{kg}]$} & {$[\%]$} & {$[\mathrm{kg}]$} & {$[\%]$} \\
\hline Energy/industry & 23.7 & 12.9 & 13.5 & 5.4 & 754.1 & 40.4 & 82.6 & 1.6 & 61.8 & 17.2 \\
\hline Residential & 160.2 & 87.1 & 233.9 & 93.9 & 736.9 & 39.5 & 1473.7 & 29.3 & 204.0 & 56.7 \\
\hline Transport & - & & 1.6 & 0.6 & 374.2 & 20.1 & 3469.6 & $69 ., 0$ & 94.0 & 26.1 \\
\hline Total & 183.9 & 100 & 249.0 & 100 & 1865.2 & 100 & 5025.9 & 100 & 359.8 & 100 \\
\hline
\end{tabular}

characteristics of power and heating plants which feed the district heating system operating in Warsaw.

Finally, the aggregate emission field was divided into the six basic categories, mainly based on technological parameters, emission characteristics and the intrinsic data uncertainty. The six categories and the quantity of the individual sources in each category, are:

- High point sources (24) - mainly the energy sector (power or heating plants);

- Low point sources (3880) - other point sources (industry or the local heating installations);

- Area sources 6962) - residential sector;

- Line sources (7285) - urban road transport;

- Agriculture sources (256) - agricultural activity, mainly in peripheral districts and suburban area (also represented as the area sources);

- $\mathrm{BC}$ - boundary conditions (the transboundary pollution inflow from sources at the national/regional level).

As mentioned before, the total emission field encompasses the Warsaw area in the administrative borders and the surrounding belt of approximately $30 \mathrm{~km}$ width (compare Fig. 1). Locations of the point sources are given in the geographical coordinates. The area and line sources are represented as basic grid emission squares, $0.5 \mathrm{~km} \times 0.5 \mathrm{~km}$, inside Warsaw administrative borders, and more aggregated, $1 \mathrm{~km} \times 1 \mathrm{~km}$, in the surroundings. The local city areas in the suburban belt are also represented by the nested $0.5 \mathrm{~km} \times 0.5 \mathrm{~km}$ grid, as seen in Fig. 2 below.

Air pollutants originated from the agriculture sector have a minor impact on the urban atmospheric environment, especially when compared with the activity of the transportation system, the industry or residential sector. The sources which represent the emissions from farming, soil cultivation and cultivating machinery, are mainly located in the suburban districts and are represented by theareagridcellswithaggregated spatialresolution, $5 \mathrm{~km} \times 5 \mathrm{~km}$.

The shape and the structure of the emission fields considered below are illustrated by two $\mathrm{PM}_{10}$ emission maps shown in Fig. 2, which represent the area (top) and line (bottom) sources, respectively. The maps take into account the variability of the spatial resolution in the urban area and the surroundings.
The transboundary inflow from the regional/national scale emission source are included as boundary conditions in the extended Warsaw area. The boundary concentrations of the main pollutants are based on the EMEP model simulations in Poland in the year considered.

\section{Meteorological data}

The input dataset for the year 2012 used in computations, also employed in (Holnicki et al. 2016), cover the main meteorological fields, including wind, pressure, cloudiness, precipitation, etc. The original data sequence was re-analyzed by the mesoscale numerical meteorological WRF model (NCAR 2008) and then transformed by the CALMET preprocessor to the input data required by CALPUFF in the proper format and resolution. Within this step, additional parameters were also generated, e.g. inversion height and atmospheric stability class. The full terrain characteristic was used to assess the aerodynamic roughness parameter and generate the final wind field which was interpolated to the grid resolution used by the main model. The data (similarly as for the emissions) are finally prepared as a sequence of one hour episodes which cover the yearly time interval. The wind rose plot for Warsaw, based on measurements (WIOŚ 2012) is presented in Fig. 3.

\section{Modeling results}

The main objective of numerical simulation was to assess the annual mean concentrations of the polluting species under consideration at the receptor sites. The recorded concentration values of the main polluting components that characterize Warsaw atmospheric environment, are interpolated to the pollution maps shown in the figures below (ArcMap software is used). Due to the space limits, the resulting concentration maps presented below relate to the key pollutants rather than all of those listed in Table 1, namely, particulate matter, nitrogen and sulfur oxides, lead, and benzo(a)pyrene.

Figure 4 shows concentration maps of the particulate matter, $\mathrm{PM}_{10}$ and $\mathrm{PM}_{2.5}$, which strongly affect air quality in most of urban agglomerations. As seen in Table 2, in the Warsaw domain these pollutants get into the atmosphere 

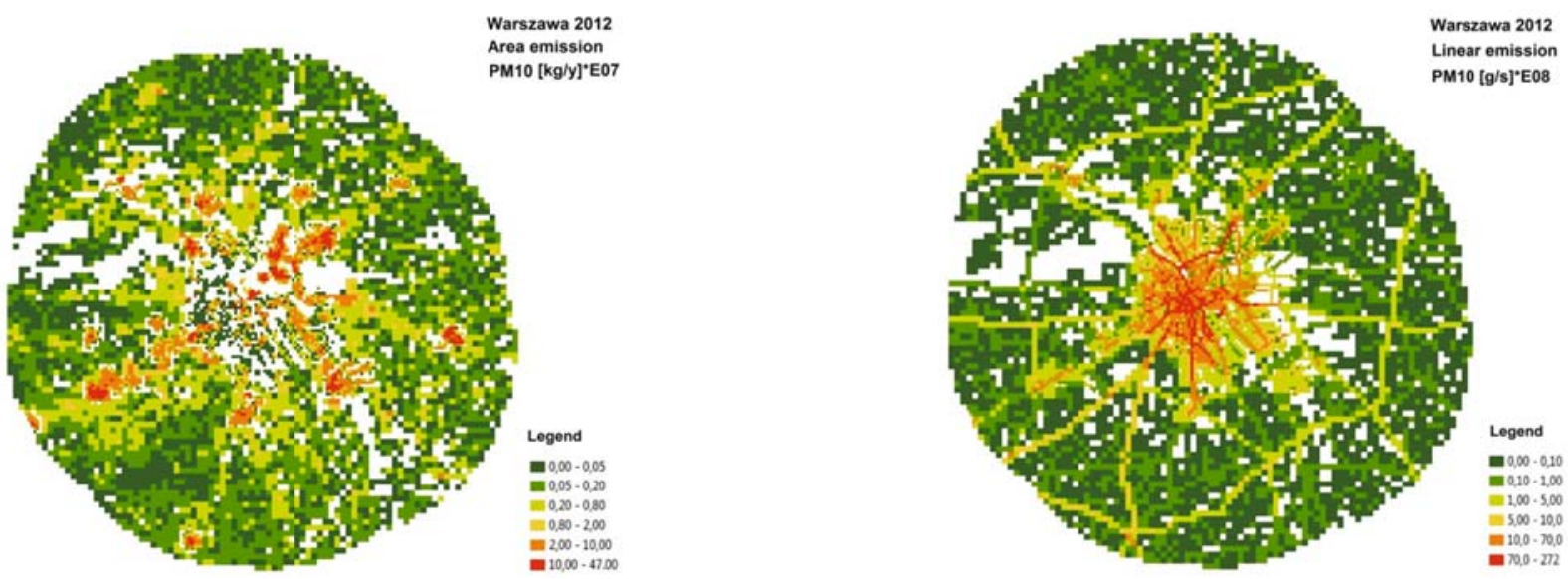

Fig. 2. The $\mathrm{PM}_{10}$ emission fields for the area sources (top) and the line sources (bottom)

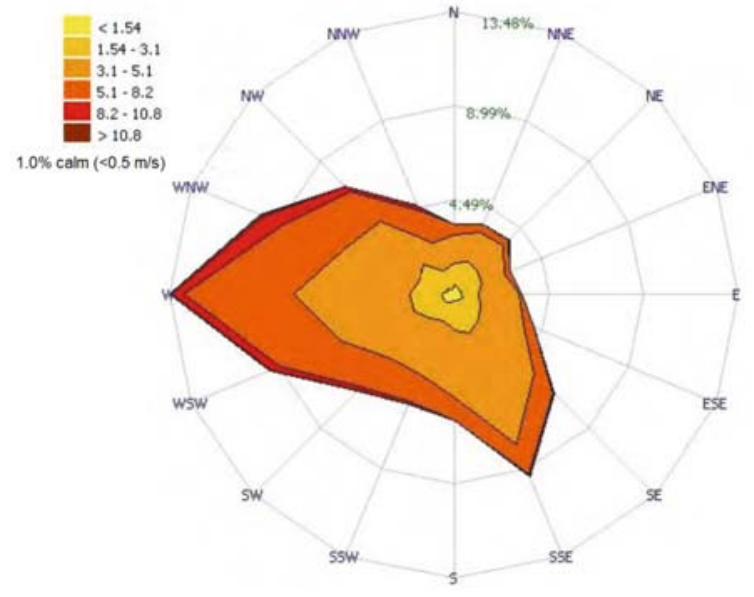

Fig. 3. Wind rose for the Warsaw agglomeration in 2012 (Holnicki et al. 2016)

mainly from the road transport system $\left(\mathrm{PM}_{10}-62 \%\right.$ and $\mathrm{PM}_{2.5}$ $-27 \%)$ and from the residential sector $\left(\mathrm{PM}_{10}-38 \%\right.$ and $\mathrm{PM}_{2.5}$ $-53 \%)$. The transboundary inflow from distant sources is also significant and mainly contains the fine fraction of $\mathrm{PM}_{2.5}$, which is confirmed in Fig. 7 below. As seen from Fig. 4, the annual mean concentrations, both for $\mathrm{PM}_{10}$ and $\mathrm{PM}_{2.5}$, exceed the limits (CAFE 2008) adopted by the Polish Ministry of Environment (ME 2012): $40 \mu \mathrm{g} / \mathrm{m}^{3}$ for $\mathrm{PM}_{10}$ and $25 \mu \mathrm{g} / \mathrm{m}^{3}$ for $\mathrm{PM}_{2.5}$. Violation of these standards occurs mainly in the central $\left(\mathrm{PM}_{10}\right)$ and $\mathrm{S}-\mathrm{W}$ districts $\left(\mathrm{PM}_{2.5}\right)$, but the composition depends on the dominant emission category and on receptor location, and is different for both PM fractions (see below).

As seen in Fig. 4, $\mathrm{PM}_{10}$ concentrations are highly correlated with the topology of the arterial streets (mobile sources), while those of $\mathrm{PM}_{2.5}$ depend more on emissions from residential sources (individual heating/cooking installations) and transboundary inflow of the fine PM fractions. Figure A1 shows the shares of emission classes contributing to the resulting $\mathrm{PM}_{10}$ or $\mathrm{PM}_{2.5}$ pollution in the receptor's location. The contribution of the traffic sources dominates in the central districts and in the vicinity of the main streets. In the peripheries there is a strong impact of the area sources of the local heating installations.

The linear structure of the CALPUFF model allows to compute individually the contribution of each source to an overall concentration in any receptor site. The differences in source apportionment between $\mathrm{PM}_{10}$ and $\mathrm{PM}_{2.5}$ are illustrated in Fig. 7 (top), where two exemplary receptors are considered: \#1217 - the crossroad of two arterial streets, and \#658, representing a residential area (S-W periphery). Abbreviations used in Fig. 7 denote the emission categories: LIN - line sources, AREA - area sources, HIGH - high point sources, LOW - other point sources, AGR - agriculture sources, BC - transboundary inflow via boundary conditions.

The vicinity of the main crossroad (\#1217) shows the strong domination of the line sources in $\mathrm{PM}_{10}$ pollution. The major contributor in this case is the re-suspended emission (compare Table 1), with the dominating coarse fractions of PM. The fine components of the re-suspended PM pollution contribute only about $14 \%$ to the total. On the other hand, in the case of $\mathrm{PM}_{2.5}$ pollution, the impact of the housing sector (area sources) and that of the transboundary inflow dominate at both receptor sites. This follows from the very high share of the fine PM fractions in the long distance transport, with relatively high participation of the sulfate and nitrate aerosols in the transported air pollutants, since time is a key factor in the aerosol formation (Oxley et al. 2009, Trapp 2010, ETC/ACM 2013). Due to low deposition velocity, these fractions remain suspended longer in the atmosphere. The diagrams in Fig. 7 show that the overall $\mathrm{PM}_{2.5}$ concentration in the residential area is higher than that near the crossroad, contrary to that for $\mathrm{PM}_{10}$. Moreover, the share of $\mathrm{PM}_{2.5}$ concentration in total PM pollution is $67 \%$ at the housing receptor and only $47 \%$ at the crossroad.

Concentration maps for gaseous $\mathrm{NO}_{\mathrm{X}}$ and $\mathrm{SO}_{2}$ pollutions are shown in Figure 5. The spatial distribution of $\mathrm{NO}_{\mathrm{x}}$ concentration, which is a typical traffic-originated pollutant, reflects the topology of the road network (Fig. A2, upper panel), where the maximum values coincide with the main arterial streets (compare also Patton et al. 2014). This is additionally confirmed by the source apportionment graph for $\mathrm{NO}_{\mathrm{X}}$ pollution at the crossroad receptor site (Fig. 7). Concentrations of the nitrogen oxides strongly exceed (more than twice) the value of $30 \mu \mathrm{g} / \mathrm{m}^{3}$. This occurs mainly (Fig. 5, upper panel) in the city center and in the neighborhoods of the main streets. Concentrations of $\mathrm{SO}_{2}$ are below the level of $20 \mu \mathrm{g} / \mathrm{m}^{3}$ (CAFE 2008, ME 2012) on the whole Warsaw territory. The pollution structure (Fig. A2) depends on the receptor's location and reflects the neighboring emission sources.

Figure 7 shows the share of emission classes for $\mathrm{NO}_{\mathrm{x}}$ and $\mathrm{SO}_{2}$ at the same receptor points, $\# 1217$ and $\# 658$. In the first case 
$\left(\mathrm{NO}_{\mathrm{x}}\right)$, a definite domination of the line sources is seen, especially at the crossroad receptor, where $93 \%$ of pollution comes from the mobile sources. On the other hand, all the source categories contribute to $\mathrm{SO}_{2}$ emission, with the significant domination of the point sources $(87 \%)$ and a comparable share of the area and line emission (Table 2). Due to the high stacks of power and heating plants, the apportionment of this sector to the resulting $\mathrm{SO}_{2}$ concentration over the Warsaw area is minor. As a consequence, the residential and line emission sources are the main determinant of the spatial distribution of this type of pollution.
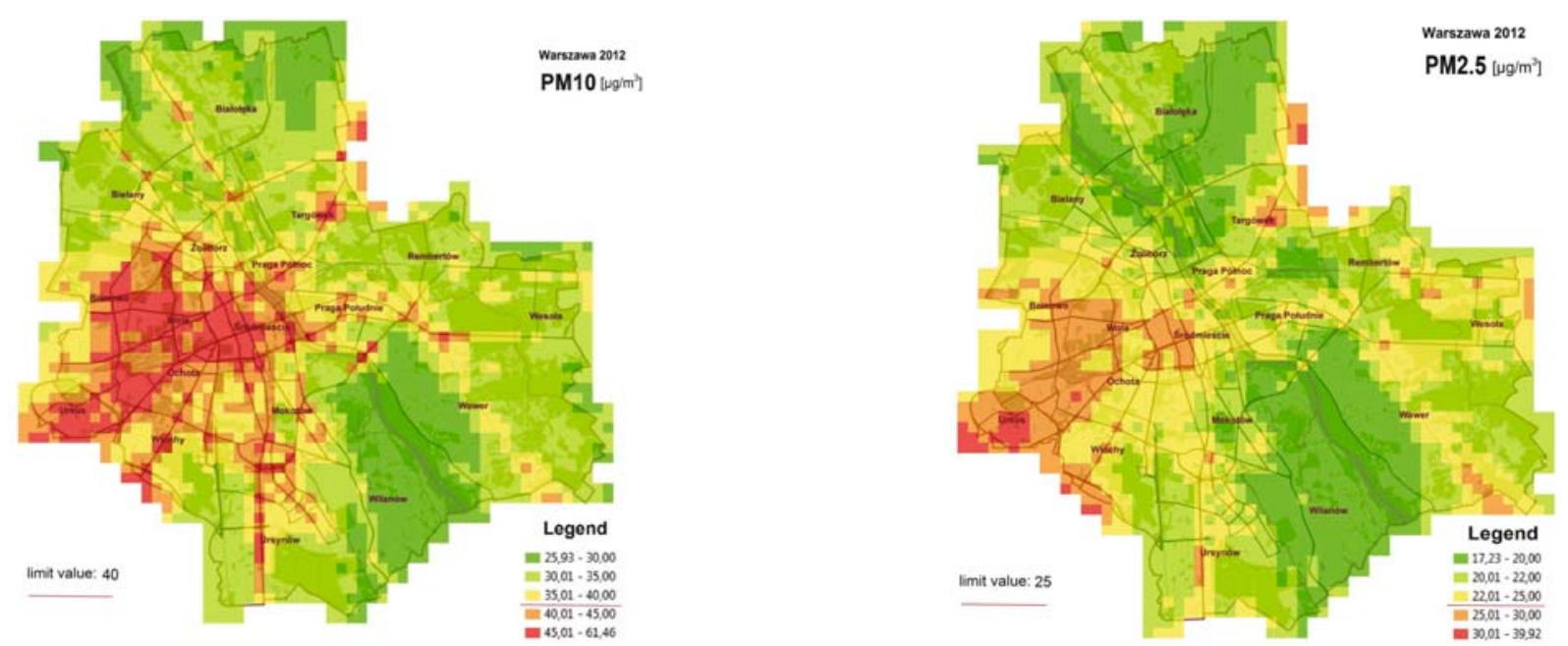

Fig. 4. The computed annual mean concentrations of $P M_{10}$ (Holnicki et al. 2016) and $\mathrm{PM}_{2.5}$
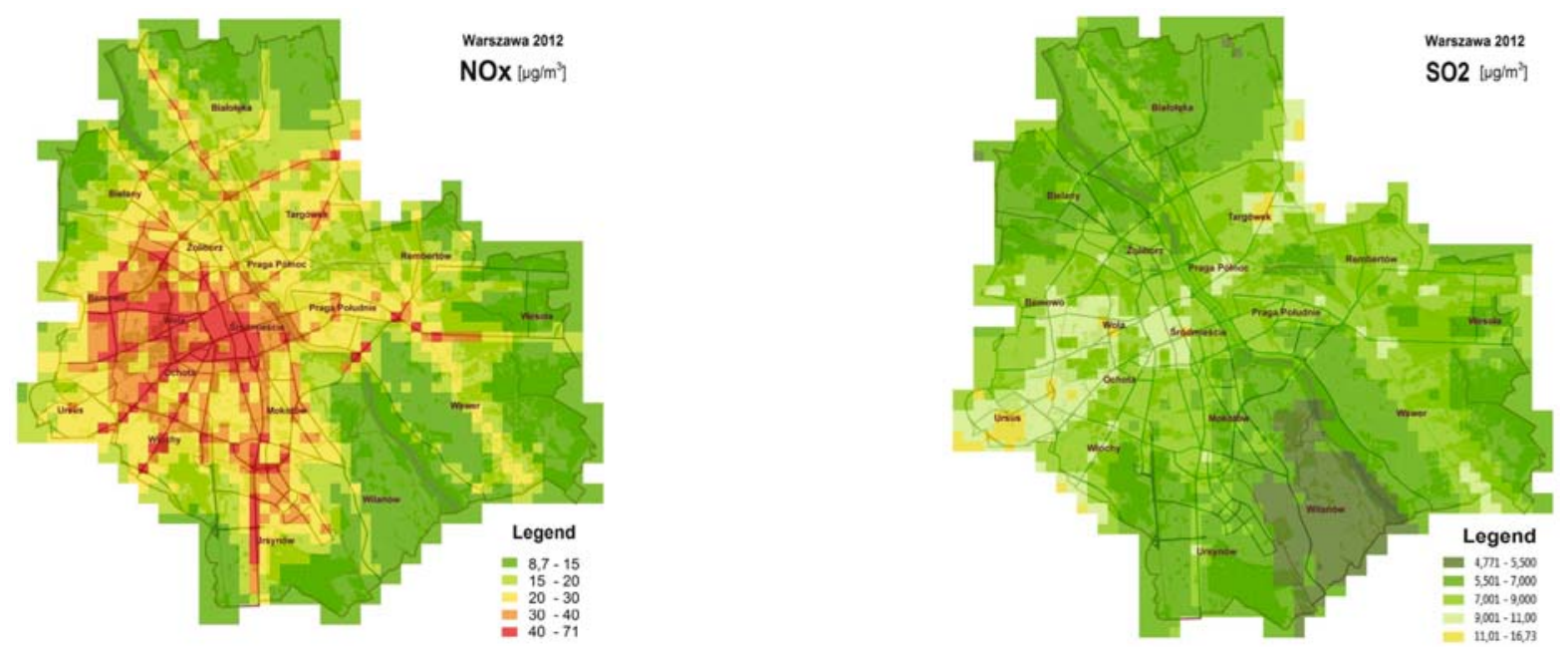

Fig. 5. The computed annual mean concentrations of $\mathrm{NO}_{x}$ (Holnicki et al. 2016) and $\mathrm{SO}_{2}$
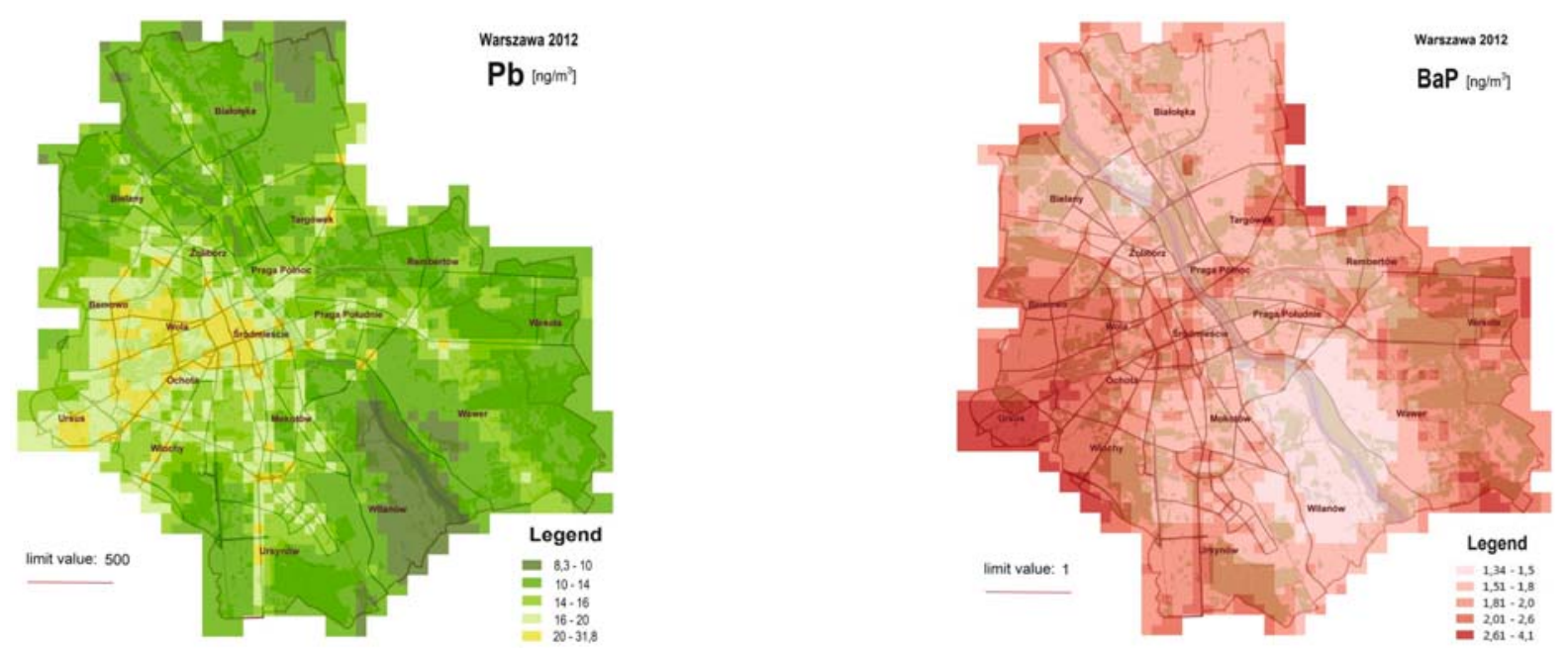

Fig. 6. The computed annual mean concentrations of $\mathrm{Pb}$ and $\mathrm{B}(\mathrm{a}) \mathrm{P}$ 

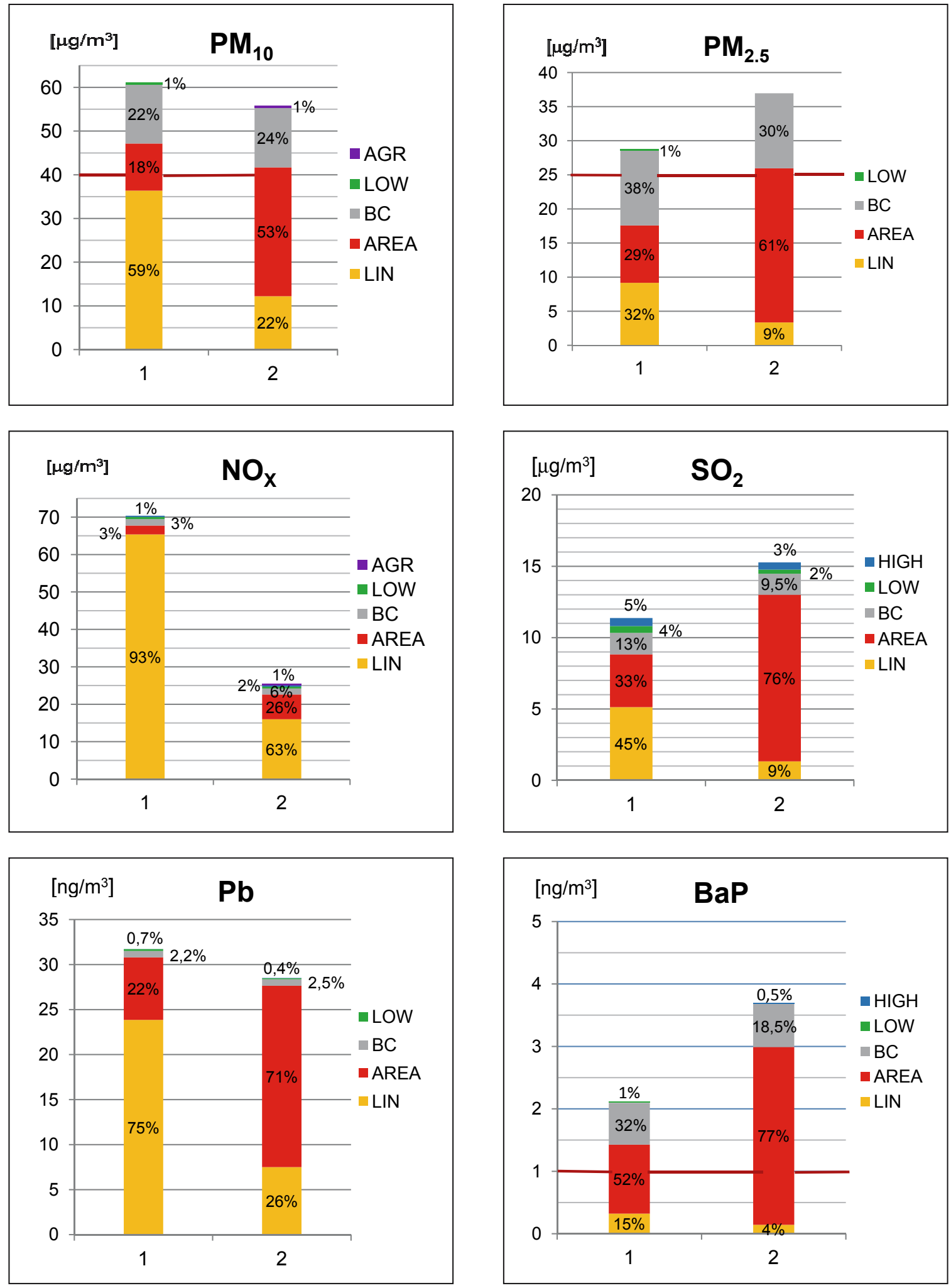

Fig. 7. The share of emission categories depending on receptor's location (1) Receptor \#1217 (crossroad), (2) Receptor \#658 (housing)

The area sources (mainly the small scale coal fired installation in the residential areas) definitely dominate in $\mathrm{SO}_{2}$ pollution of the residential districts (Fig. 7, middle), while the traffic emission (line sources) contributes greatly to $\mathrm{SO}_{2}$ concentration near the arterial streets and crossroads.

Concentration maps for $\mathrm{Pb}$ and $\mathrm{B}(\mathrm{a}) \mathrm{P}$ are presented in Figure 6. The lead concentrations in Warsaw are definitely below the limit value $\left(500 \mathrm{ng} / \mathrm{m}^{3}\right)$, but the spatial distribution apparently coincides with the shape of the street network. Similarly as for $\mathrm{NO}_{\mathrm{X}}$, lead pollution is highly correlated with emission from the line sources, but at very low concentration levels. According to WIOŚ (2012), the recorded $\mathrm{Pb}$ emission originates from road traffic, given that a small share of old vehicles still use leaded gasoline. As seen from Table 2, the 
line sources are responsible for $69 \%$ of the total $\mathrm{Pb}$ emission, while the remaining part comes from the residential sector. As also shown in Fig. A3, the line sources (which dominate in the center) and the local area emission are the main emission categories responsible for this pollution.

The severe environmental problem is connected with the $\mathrm{B}(\mathrm{a}) \mathrm{P}$ pollution, responsible for strong adverse health effects (EEA 2012). The concentration limit, adopted by the Polish Ministry of Environment, $1 \mathrm{ng} / \mathrm{m}^{3}$ (EEA 2012, ME 2012) is surpassed in the whole area of Warsaw (Fig. 6). The highest standard violations, about $3-4 \mathrm{ng} / \mathrm{m}^{3}$, occur in the peripheral area, mainly near the S-W border (Włochy and Ursus residential districts). The main source of this pollution is the residential sector - the small scale coal fired heating installations, which to a large extent are also responsible for high concentrations of $\mathrm{PM}_{2.5}$ or $\mathrm{SO}_{2}$.

The above findings are illustrated by the diagrams shown in Fig. 7 (bottom). Lead concentration at the crossroad site strongly depends on the traffic intensity, but the contribution of the local heating dominates in the residential areas. The local heating activity is also the main source of very harmful $\mathrm{B}(\mathrm{a}) \mathrm{P}$ pollution, which is mainly observed in the peripheral districts of the agglomeration. Local coal combustion can be a source of about $80 \%$ of $\mathrm{B}(\mathrm{a}) \mathrm{P}$ pollution in such regions, as shown in Fig. 7. Moreover, about $67 \%$ of the B(a)P limit concentration comes from the transboundary inflow (compare also Fig. A3), and from similar sources located in the outskirt of the study area.

\section{Assessments of the model performance}

Comparison with observations allows for evaluation of the overall model accuracy. Fig. 1 shows the locations of eleven stationary air quality monitoring stations, nine of which were operating in 2012. Short characteristics of each station are presented in Table 3, including the list of the polluting components which are observed in them. The measurements of 1-h concentrations are performed automatically, and some 24-h average observations are gathered manually. In particular, the operation of station \#7 is based on the manual, 24-h measurements of the components of $\mathrm{PM}_{10}$ : heavy metals and polycyclic aromatic hydrocarbons, including $\mathrm{B}(\mathrm{a}) \mathrm{P}$. The annual mean concentrations based on the observation data were compared with the computed concentrations at the same receptor sites. As shown in Table 3, each station measures the selected set of compounds. Referring to the main pollutants considered in the study, the following numbers of the measurement results are available: $\mathrm{NO}_{\mathrm{X}}-5, \mathrm{SO}_{2}$ $-5, \mathrm{PM}_{10}-4, \mathrm{PM}_{2.5}-3, \mathrm{CO}-4, \mathrm{C}_{6} \mathrm{H}_{6}-2$. Only one measurement point is available for $\mathrm{B}(\mathrm{a}) \mathrm{P}$ and heavy metals (measurement station \#7).

The commonly used metrics to quantify the difference between modelled and observed concentrations are the normalized mean bias, NMB, the fractional bias, FB, and the normalized mean square error, NMSE (Dernwent et al. 2010, Juda-Rezler 2010, ETC/ACM 2013). In the first two metrics the sign of the difference is taken into account, which allows for assessing the under- and over-estimations. Another very useful metric is the FAC2 index, based on a scatter plot of points, where the ratio between the model prediction value and the corresponding observation should be between 0.5 and 2 . The definitions of the above metrics are as follows:

Normalized Mean Bias, $N M B=\sum_{k=1}^{n}\left(C_{o k}-C_{m k}\right) / \sum_{k=1}^{n} C_{o k}$

Fractional Bias,

$$
F B=2\left(\bar{C}_{o}-\bar{C}_{m}\right) /\left(\bar{C}_{o}+\bar{C}_{m}\right)
$$

Normalized Mean

Square Error,

$$
N M S E=\sum_{k=1}^{n}\left(C_{o k}-C_{m k}\right)^{2} / n \bar{C}_{o} \bar{C}_{m}
$$

Fraction of two,

$$
0.5 \leq F A C 2=C_{m k} / C_{o k} \leq 2
$$

where: $C_{o}, C_{m}-$ observed and modeled concentrations, $\bar{C}_{o}, \bar{C}_{m}$ - the mean values, $n$ - the number of the observation points. Table 4 shows the first three metrics for six basic pollutants,

\begin{tabular}{|c|c|c|c|c|c|}
\hline No & Site code & Site coordinates $\left[{ }^{\circ}\right]$ & $\begin{array}{l}\text { Related } \\
\text { Receptor }\end{array}$ & Measurements & Site type \\
\hline 1 & MzWarNiepodKom & $(21.005 ; 52.219)$ & 1022 & $\mathrm{NO}_{\mathrm{X}}, \mathrm{PM}_{10}, \mathrm{PM}_{2.5}, \mathrm{C}_{6} \mathrm{H}_{6}, \mathrm{CO}$ & Traffic \\
\hline 2 & MzWarszKrucza & $(21.019 ; 52.225)$ & 1134 & $\mathrm{SO}_{2}, \mathrm{NO}_{x}, \mathrm{CO}$ & Urban background \\
\hline 3 & MzWarszBernWoda & $(21.051 ; 52.192)$ & 694 & $\mathrm{SO}_{2}$ & Industrial \\
\hline 4 & MzWarszMarsz & $(21.015 ; 52.225)$ & 1027 & $\mathrm{CO}$ & Traffic \\
\hline 5 & MzWarszUrsynow & $(21.034 ; 52.161)$ & 370 & $\mathrm{SO}_{2}, \mathrm{NO}_{x}, \mathrm{PM}_{10}, \mathrm{PM}_{2.5}, \mathrm{C}_{6} \mathrm{H}_{6}$ & Urban background \\
\hline 6 & MzWarszPuszSolska & $(20.909 ; 52.226)$ & 1105 & $\mathrm{SO}_{2}, \mathrm{NO}_{\mathrm{x}}$ & Industrial \\
\hline 7 & MzWarszAKrzywon & $(20.918 ; 52.229)$ & 1109 & $\mathrm{PM}_{10}, \mathrm{~B}[\mathrm{a}] \mathrm{P}, \mathrm{As}, \mathrm{Cd}, \mathrm{Ni}, \mathrm{Pb}$ & Urban background \\
\hline 8 & MzWarPodIMGW & $(20.962 ; 52.281)$ & 1726 & inactive & Urban background \\
\hline 9 & MzWarszBielan & $(20.933 ; 52.285)$ & 1718 & inactive & Urban background \\
\hline 10 & MzWarTarKondra & $(21.042 ; 52.291)$ & 1825 & $\mathrm{SO}_{2}, \mathrm{NO}_{\mathrm{x}}, \mathrm{PM}_{10}, \mathrm{PM}_{2.5}, \mathrm{CO}$ & Urban background \\
\hline 11 & MzWarszPoraj & $(20.959 ; 52.315)$ & 1932 & $\mathrm{NO}_{\mathrm{x}}$ & Industrial \\
\hline
\end{tabular}
where at least two measurement points are available. Similar

Table 3. Characteristics of the monitoring stations 
estimates can be found in (Trapp 2010) for $\mathrm{PM}_{10}, \mathrm{NO}_{2}$ and $\mathrm{SO}_{2}$ in Mazovian Voivodship or in (Elbir 2003) for $\mathrm{SO}_{2}$ in Izmir.

Table 5 shows the computed and calculated concentrations at nine monitoring sites, as well as the values of FAC2 index (see also Holnicki and Nahorski 2015, Juda-Rezler 2010, Trapp 2010) for the above six basic compounds. Similar assessments, for the limited number of the measurement stations, are shown in (Holnicki et al. 2016). Most of the results satisfy the accuracy standard, $0.5 \leq$ FAC $2 \leq 2$. The only exception relates to the monitoring station \#1, where the model $\left(60 \mu \mathrm{g} / \mathrm{m}^{3}\right)$ underestimates the measured $\mathrm{NO}_{\mathrm{x}}$ concentration $\left(143 \mu \mathrm{g} / \mathrm{m}^{3}\right)$. This case, however, refers to a traffic observation, where the point-wise, street-canyon measurement is performed (compare Rzeszutek and Bogacki 2016), while the model calculates a spatially averaged concentration.

The computed CO concentrations are very low, in the range of 200-700 $\mu \mathrm{g} / \mathrm{m}^{3}$ (Table 5), as compared with the limit value, $10,000 \mu \mathrm{g} / \mathrm{m}^{3}$. Consequently the share of the transboundary inflow, amounting to nearly $130 \mu \mathrm{g} / \mathrm{m}^{3}$, is considerable. The pollution in the center is mainly due to mobile source emission
(Table 2), with a higher share of the inflow in the peripheral districts (Fig. A4). On the other hand, the line emission is a dominating contributor to $\mathrm{C}_{6} \mathrm{H}_{6}$ in the central districts, while the high point sources (major power plants) or the low point sources (local industry) have a substantial share locally, e.g. in some peripheral districts (see Fig. A4). The accuracy results (Table 4) show a slight underestimation of $\mathrm{CO}$ and similar overestimation of $\mathrm{C}_{6} \mathrm{H}_{6}$ concentrations, however FAC2 criteria are satisfied.

The manual monitoring station \#7 is the only one where the measurements of four heavy metals ( $\mathrm{As}, \mathrm{Cd}, \mathrm{Pb}, \mathrm{Ni}$ ) and $\mathrm{B}(\mathrm{a}) \mathrm{P}$ pollutions are performed. As shown in Figs. 6-7, the annual average $\mathrm{B}(\mathrm{a}) \mathrm{P}$ concentration in Warsaw violates the limit value $1 \mathrm{ng} / \mathrm{m}^{3}$. The measured value of monitoring station \#7 is $3.1 \mathrm{ng} / \mathrm{m}^{3}$ while the respective model prediction value is $2.1 \mathrm{ng} / \mathrm{m}^{3}(\mathrm{FAC} 2=0.68)$.

Table 6 shows the limit concentration of lead in 2012 and the more restrictive target values for other heavy metals, in force since 1st January 2013 according to EU (2008) and ME (2012). The threshold values are compared with the corresponding

Table 4. The model accuracy metrics (dimensionless)

\begin{tabular}{|c|c|c|c|c|c|c|}
\hline & $\mathrm{PM}_{10}$ & $\mathrm{PM}_{2.5}$ & $\mathrm{NO}_{x}$ & $\mathrm{SO}_{2}$ & $\mathrm{CO}$ & $\mathrm{C}_{6} \mathrm{H}_{6 .}$ \\
\hline $\mathrm{NMB}$ & 0.123 & -0.088 & -0.079 & 0.034 & -0.239 & 0.252 \\
\hline $\mathrm{FB}$ & 0.116 & -0.092 & -0.083 & 0.034 & -0.272 & 0.224 \\
\hline NMSE & 0.004 & 0.002 & 0.070 & 0.073 & 0.123 & 0.123 \\
\hline
\end{tabular}

Table 5. Modeled vs. observed concentrations $\left(\mu \mathrm{g} / \mathrm{m}^{3}\right)$ and FAC2 index

\begin{tabular}{|c|c|c|c|c|c|c|c|c|c|c|c|c|}
\hline \multirow[b]{2}{*}{ Site No } & \multicolumn{2}{|c|}{$\mathrm{PM}_{10}$} & \multicolumn{2}{|c|}{$\mathrm{PM}_{2.5}$} & \multicolumn{2}{|c|}{$\mathrm{NO}_{\mathrm{x}}$} & \multicolumn{2}{|c|}{$\mathrm{SO}_{2}$} & \multicolumn{2}{|c|}{$\mathrm{CO}$} & \multicolumn{2}{|c|}{$\mathrm{C}_{6} \mathrm{H}_{6}$} \\
\hline & $\frac{C_{m}}{C_{o}}$ & FAC2 & $\frac{C_{m}}{C_{o}}$ & FAC2 & $\frac{C_{m}}{C_{o}}$ & FAC2 & $\frac{C_{m}}{C_{o}}$ & FAC2 & $\frac{C_{m}}{C_{o}}$ & FAC2 & $\frac{C_{m}}{C_{o}}$ & FAC2 \\
\hline \multirow{2}{*}{ \#1 } & 51.5 & \multirow{2}{*}{1.33} & 25.6 & \multirow{2}{*}{1.0} & 59.4 & \multirow{2}{*}{0.42} & & \multirow{2}{*}{-} & 463 & \multirow{2}{*}{0.69} & & \multirow{2}{*}{-} \\
\hline & 38.6 & & 25.1 & & 143 & & & & 671 & & & \\
\hline \multirow{2}{*}{ \#2 } & & \multirow{2}{*}{ - } & & \multirow{2}{*}{ - } & 46.3 & \multirow{2}{*}{1.13} & 8.65 & \multirow{2}{*}{1.52} & 426 & \multirow{2}{*}{0.93} & 2.26 & \multirow{2}{*}{1.30} \\
\hline & & & & & 41.0 & & 5.7 & & 459 & & 1.74 & \\
\hline \multirow{2}{*}{ \#3 } & & \multirow{2}{*}{ - } & & \multirow{2}{*}{-} & & \multirow{2}{*}{-} & 7.03 & \multirow{2}{*}{1.30} & & \multirow{2}{*}{-} & & \multirow{2}{*}{-} \\
\hline & & & & & & & 5.4 & & & & & \\
\hline \multirow{2}{*}{ \#4 } & & \multirow{2}{*}{-} & & \multirow{2}{*}{-} & & \multirow{2}{*}{-} & & \multirow{2}{*}{-} & 441 & 073 & & \\
\hline & & & & & & & & & 608 & 0.10 & & \\
\hline 45 & 39.9 & 107 & 21.8 & 0 & 31.4 & & 6.8 & & & 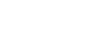 & 1.42 & \\
\hline$\pi$ & 37.2 & 1.01 & 23.1 & 0.0 & 32.1 & 0.01 & 7.0 & 0.01 & & & 1.20 & 1.10 \\
\hline & & & & & 30.1 & & 8.3 & & & & & \\
\hline & & & & & 26.6 & & 11.4 & & & & & \\
\hline$\# 7$ & 44.7 & ० 80 & & & & & & & & & & \\
\hline$H I$ & 33.1 & 0.00 & & & & & & & & & & \\
\hline & 33.5 & & 25.6 & & 21.4 & & 8.04 & & 271 & & & \\
\hline \#T & 42.1 & 1.00 & 19.9 & 0.0 & 39.8 & 0.04 & 8.0 & 1.01 & 366 & 0.14 & & \\
\hline & & & & & 31.0 & & & & & & & \\
\hline$\pi+1$ & & & & & 34.2 & 0.07 & & & & & & \\
\hline
\end{tabular}


Table 6. Heavy metals annual concentrations vs. EU Regulations (ME 2012)

\begin{tabular}{|l|c|c|c|c|}
\hline Pollutant & $\begin{array}{c}\text { Limit }(2012) \\
{\left[\mathrm{ng} / \mathrm{m}^{3}\right]}\end{array}$ & $\begin{array}{c}\text { Target }(2013) \\
{\left[\mathrm{ng} / \mathrm{m}^{3}\right]}\end{array}$ & $\begin{array}{c}\text { Computed (2012) } \\
{\left[\mathrm{ng} / \mathrm{m}^{3}\right]}\end{array}$ & FAC2 \\
\hline Arsenic & - & 6 & $0.4-2.5$ & 0.8 \\
\hline Cadmium & & 5 & $0.6-3.7$ & 3.1 \\
\hline Lead & 500 & & $8.3-32$ & 2 \\
\hline Nickel & - & 20 & $2.5-12$ & 3 \\
\hline Mercury & - & - & $0.1-15$ & - \\
\hline
\end{tabular}

ranges (min-max) of the concentrations obtained from the model computation. For all heavy metals considered in this study, the maximum concentrations are below the limits. The last column in Table 6 gives the values of FAC2 index for the four heavy metals analyzed at station \#7. For $\mathrm{Cd}$ and $\mathrm{Ni}$ the computed values tend to be overestimated.

\section{Discussion}

The results identify some categories of air pollutants which exceed the admissible concentration limits and have negative environmental impact. High concentration level of particulate matter is one of the main factors affecting adversely air quality in Warsaw. Compared with the earlier results for the year 2005 (Holnicki and Nahorski 2013), the maximum concentrations of PM fractions are higher, and the area where the limit level is exceeded has been enlarged. As shown in Fig. 4, the $\mathrm{PM}_{10}$ limit $\left(40 \mu \mathrm{g} / \mathrm{m}^{3}\right)$ is violated in the city center and in peripheral (mainly S-W) districts, while the violations of the $\mathrm{PM}_{2.5}$ limit values $\left(25 \mu \mathrm{g} / \mathrm{m}^{3}\right)$ mainly occur in the $\mathrm{S}-\mathrm{W}$ peripheries and in the close outskirt of Warsaw. In particular, a dense settlement of detached family houses along the main railroad line (SW-NE) contributes considerably to Warsaw area pollution. This effect is additionally strengthened due to the S-W wind directions which dominate in Warsaw (Fig. 3).

Source apportionment differs for both PM fractions. As seen in Fig. 7 (top) and Fig. A1, the coarser fractions of PM come mainly from the line sources (the center), with a higher impact of the area emission in the residential zones, and also with a significant share of the transboundary inflow. The dominating category in the case of $\mathrm{PM}_{2.5}$ is emission generated by detached family houses (compare Fig. A1 and Fig. 7), with a high contribution of the transboundary inflow. These are mainly fine PM fractions, transported from distant sources as the sulfate and nitrate aerosols (Table 1).

The distribution of the nitrogen oxides is typically closely related to the car traffic intensity, and Fig. 5 (top) shows the correlation between high $\mathrm{NO}_{\mathrm{x}}$ concentrations and the topology of the main streets. The city center and vicinity of arterial streets are the regions where the limit concentration level $\left(30 \mu \mathrm{g} / \mathrm{m}^{3}\right)$ is violated. Both the area of this violation and the maximum concentrations increased considerably (by about 20\%) compared with the year 2005 (Holnicki and Nahorski 2013, 2015). This deterioration was caused mainly by increasing traffic intensity in Warsaw. During the last 7 years, the number of cars has increased by about 20-25\%. Fig. 7 and Fig. A2 confirm that the mobile sources are the dominating contributor to $\mathrm{NO}_{\mathrm{x}}$ pollution, not only near the main arterial streets, but also in residential areas.
The level of $\mathrm{SO}_{2}$ concentrations in Warsaw is below the admissible limit value of $20 \mu \mathrm{g} / \mathrm{m}^{3}$ (Fig. 5) and has not changed much since the previous analysis in 2005 (Holnicki and Nahorski 2013), but the structure of the contributing emission categories is different (Fig. 7, middle). Due to the modernization of the energy sector and the lower energy consumption during the last years (energy conservation policy and the economic crisis), the share of the high point sources is much lower, also in the transboundary inflow (WIOŚ 2012). On the other hand, one can see an increase of the line source contribution in $\mathrm{SO}_{2}$ pollution, mainly in roadside receptors (Fig. 7). The residential site receptors show, similarly as for $\mathrm{PM}_{2.5}$, the dominating contribution of the area sources in $\mathrm{SO}_{2}$ concentration (Figs. 7 and A2).

The spatial distribution of $\mathrm{Pb}$ concentrations (Fig. 6) is similar to that of $\mathrm{NO}_{\mathrm{x}}$ and coincides with the main street network. During the last decade concentrations of $\mathrm{Pb}$ did not increase (compare the results in Holnicki and Nahorski (2013)) in spite of the substantial increased number of cars in Warsaw. The concentration values of $\mathrm{Pb}$, similarly as for other heavy metals, are definitely below the admissible thresholds shown in Table 6. As seen from Fig. A3, the line sources dominate in $\mathrm{Pb}$ pollution in the center, but the area sources (housing) are the main contributors in the border areas. The area sources are also dominating in As and Cd pollution and highly contribute to Ni concentrations. However, the share of the mobile sources is quite important for the latter metal. The mercury pollution is mainly due to the transboundary inflow.

Poland is among the European countries with the highest B(a)P concentrations (EEA 2012, EMEP/EEA 2013, EEA 2014), and very high concentrations of this compound are also observed in Warsaw. As shown in Fig. 6, the threshold value $\left(1 \mathrm{ng} / \mathrm{m}^{3}\right)$ is exceeded in the whole receptor area. The main source of $\mathrm{B}(\mathrm{a}) \mathrm{P}$ emission in Poland is the residential sector (Fig. 7), where simple coal-based, often obsolete, heating and cooking installations are used. The same sector is mainly responsible for $\mathrm{PM}_{25}$ pollution (EEA 2012, Chafe et al. 2014), so the spatial distributions in the concentration maps are very similar in both cases (Figs A1 and A3). Commonly used cheap but low quality coal and poor buildings insulation, cause high emissions of both $\mathrm{B}(\mathrm{a}) \mathrm{P}$ and $\mathrm{PM}_{25}$. In Warsaw, the highest concentrations of $\mathrm{B}(\mathrm{a}) \mathrm{P}$ occur in the border residential districts, mainly S-W and N-E, where the majority of detached family houses is concentrated. In Warsaw, as compared to some other Polish regions, the problem is relatively less severe and arises mainly in the border districts, because most of the town area has the city district heating system. A large share of $\mathrm{B}(\mathrm{a}) \mathrm{P}$ concentration in Warsaw, its absolute value is about $0.7 \mathrm{ng} / \mathrm{m}^{3}$, comes from the transboundary inflow. 

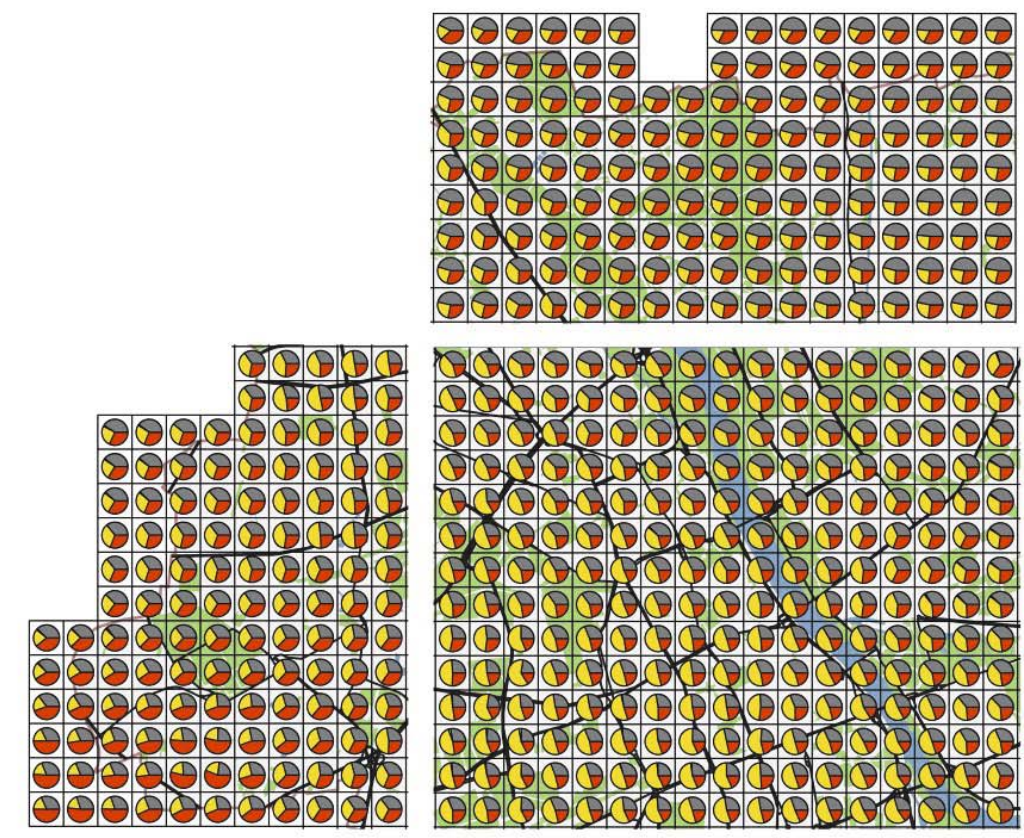

PM10 - spatial variability of sources's contribution
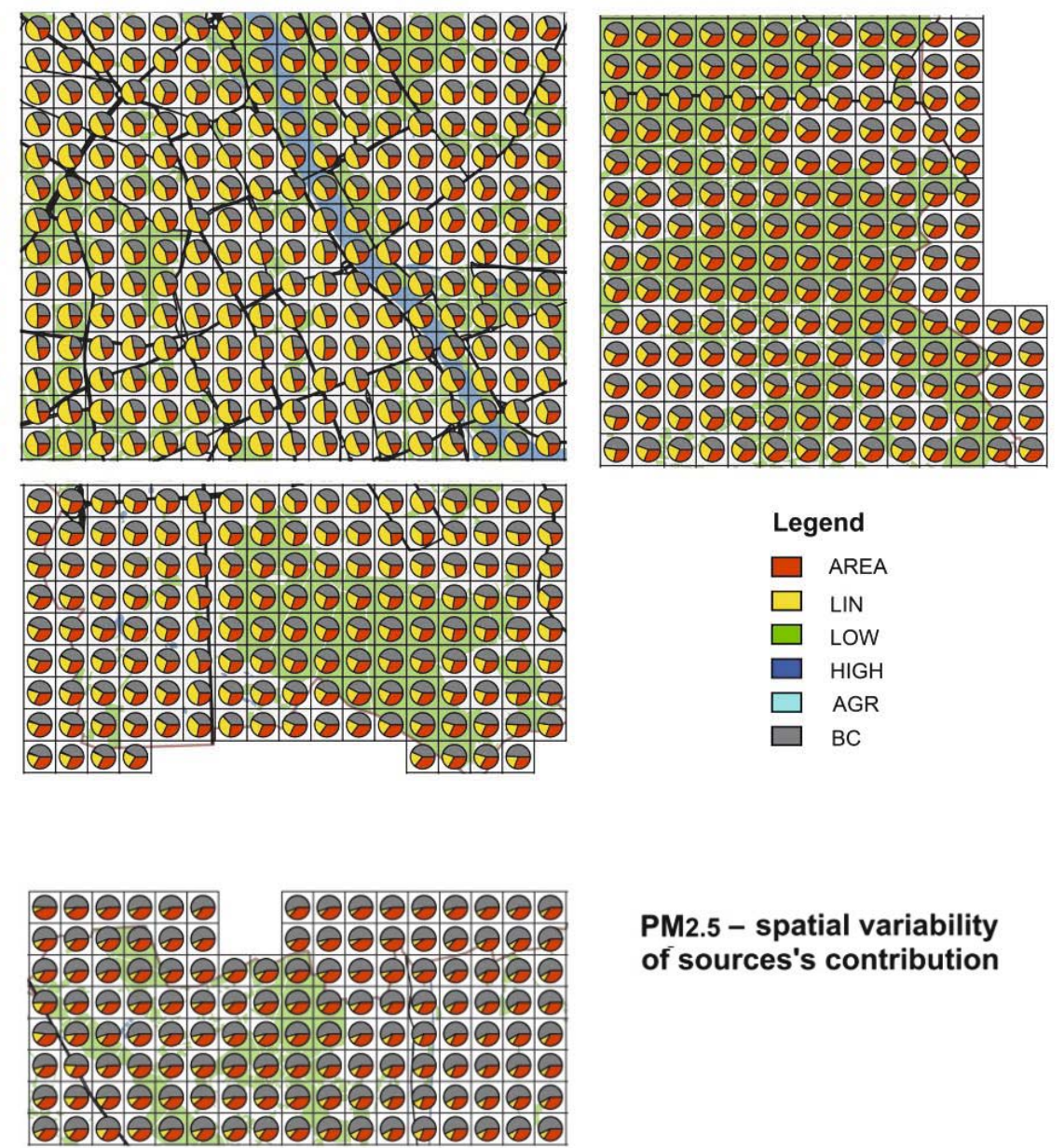

PM2.5 - spatial variability of sources's contribution
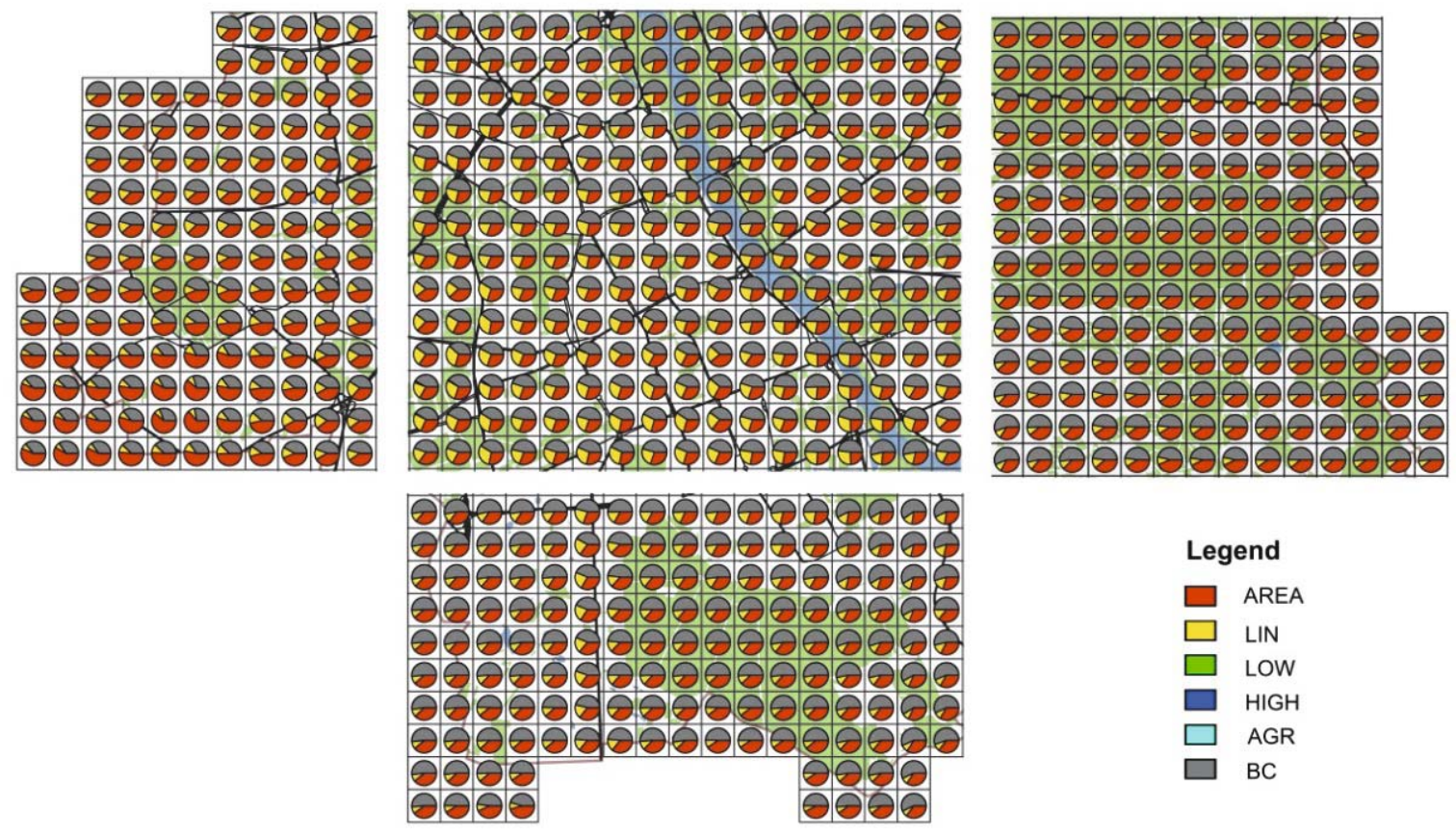
Legend
$\square$ AREA
$\square \quad$ LIN
$\square$ LOW
$\square$ HIGH
$\square$ AGR
$\square$ BC

Fig. A1. Spatial variability of the sources contribution for $\mathrm{PM}_{10}$ (top) and for $\mathrm{PM}_{2.5}$ (bottom) 


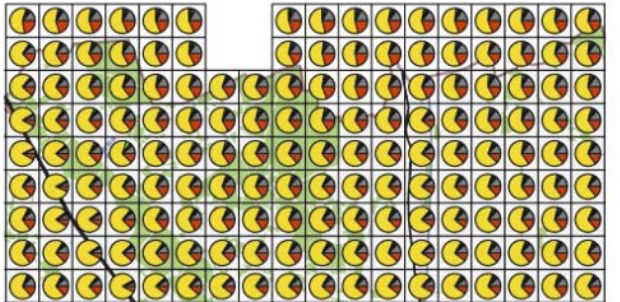

NOx - spatial variability of sources's contribution
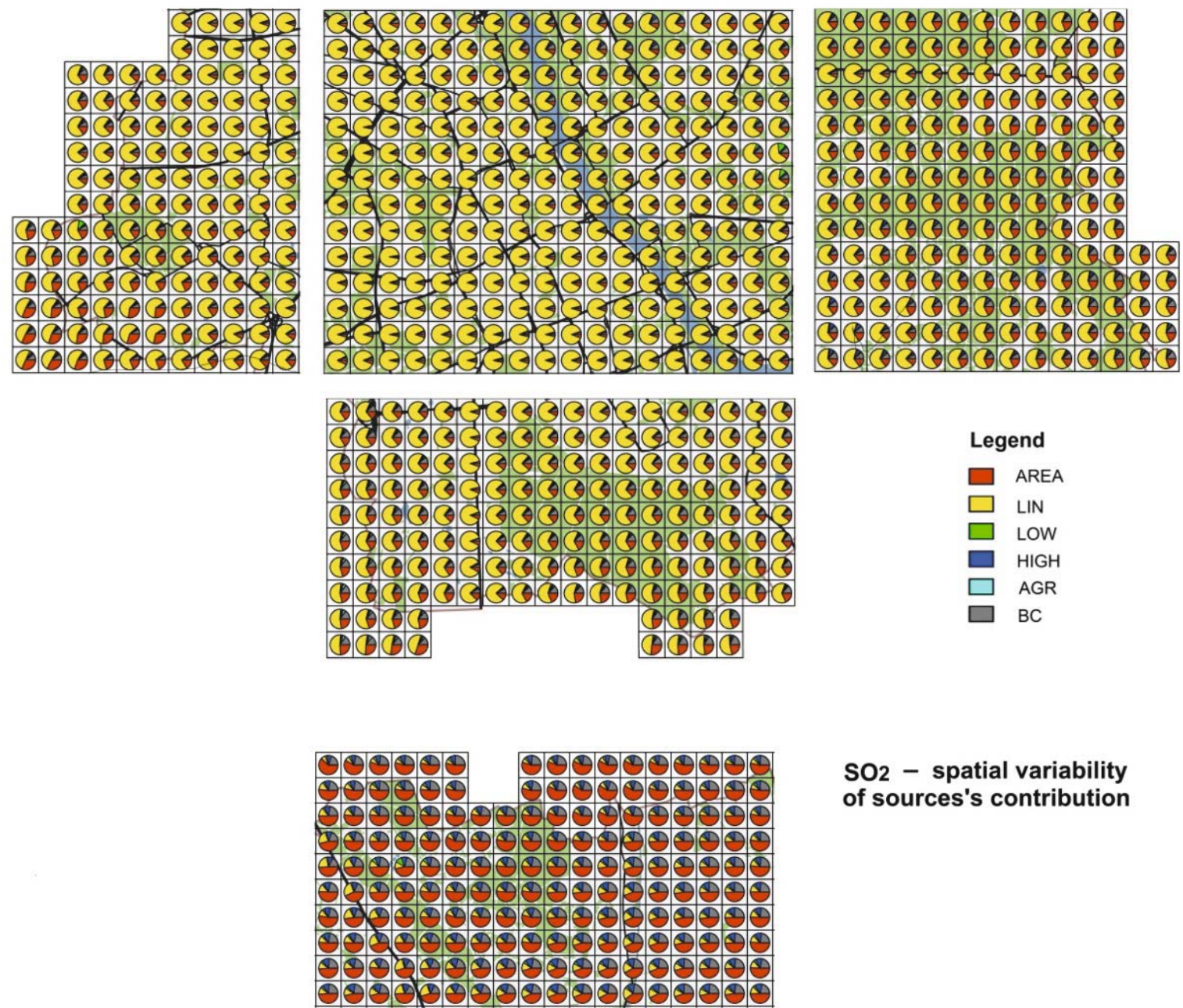

SO2 - spatial variability of sources's contribution
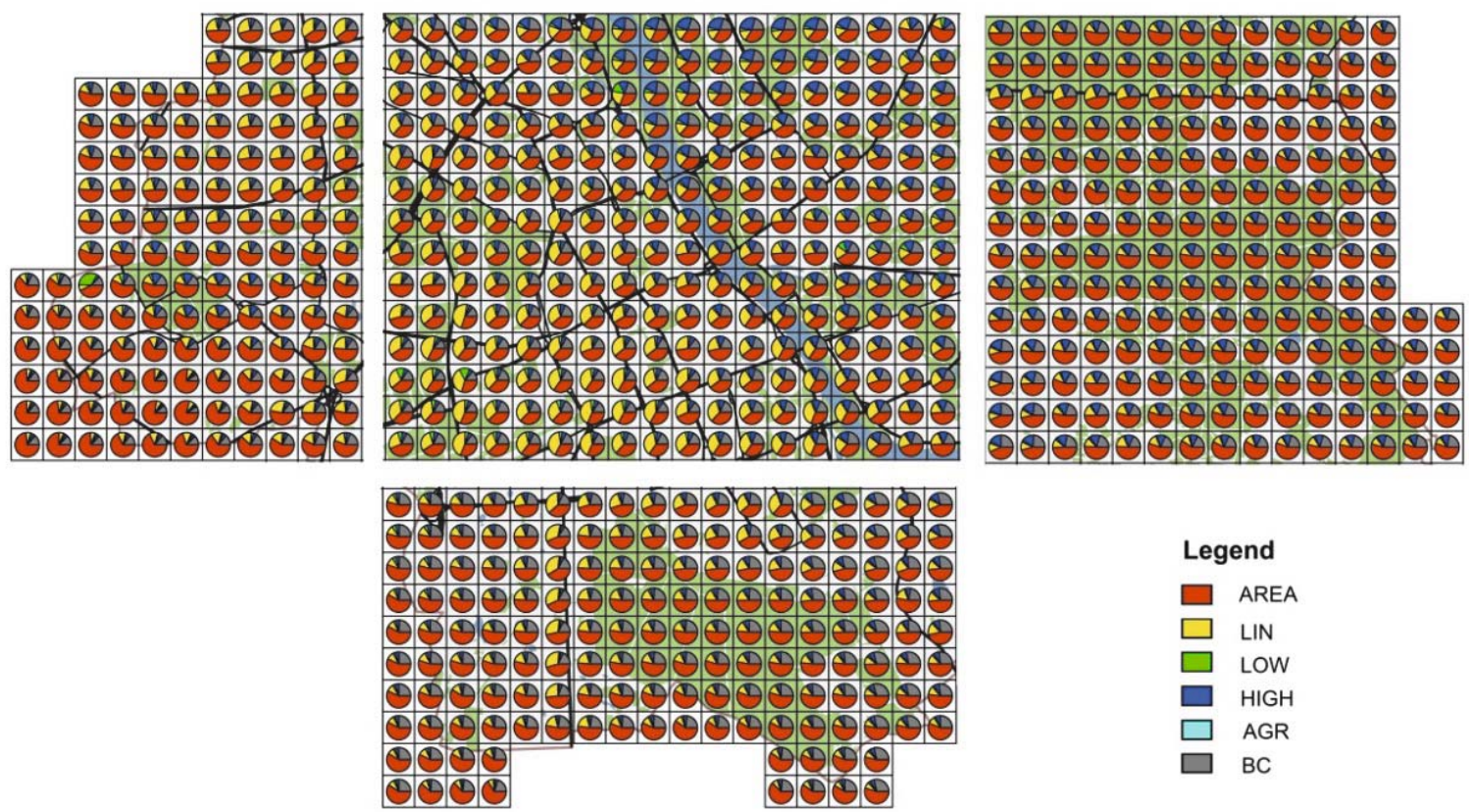

Fig. A2. Spatial variability of the sources contribution for $\mathrm{NO}_{\mathrm{x}}$ (top) and for $\mathrm{SO}_{2}$ (bottom) 

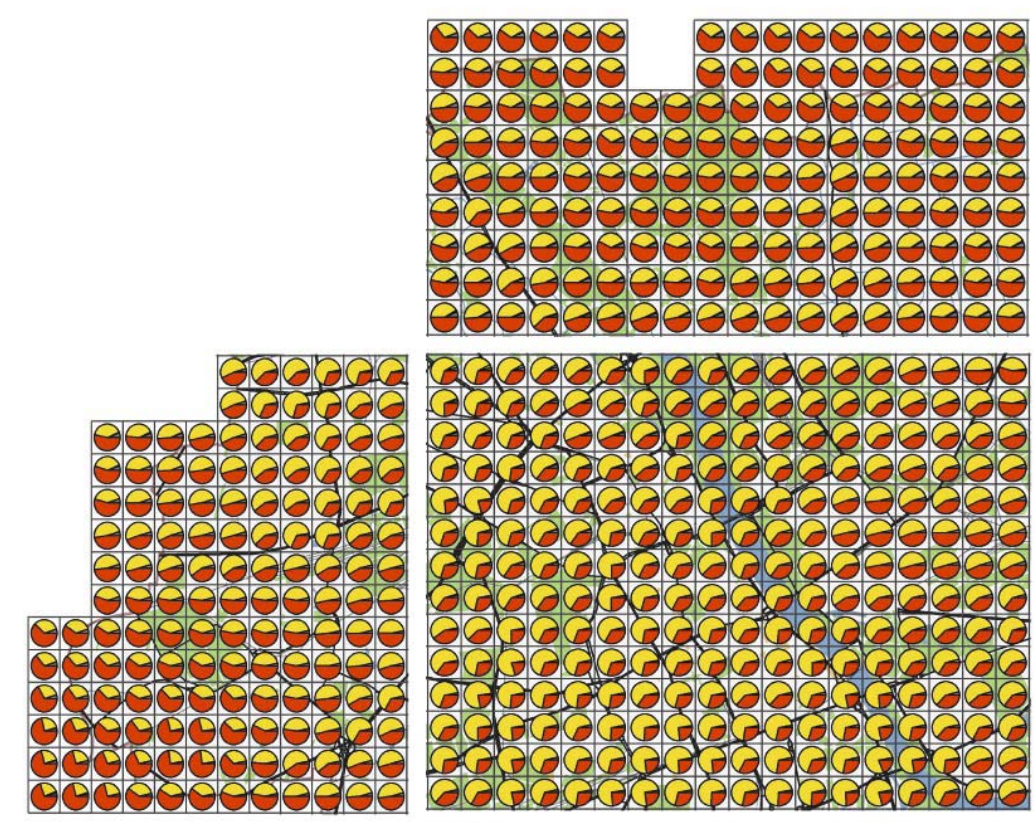

Pb - spatial variability
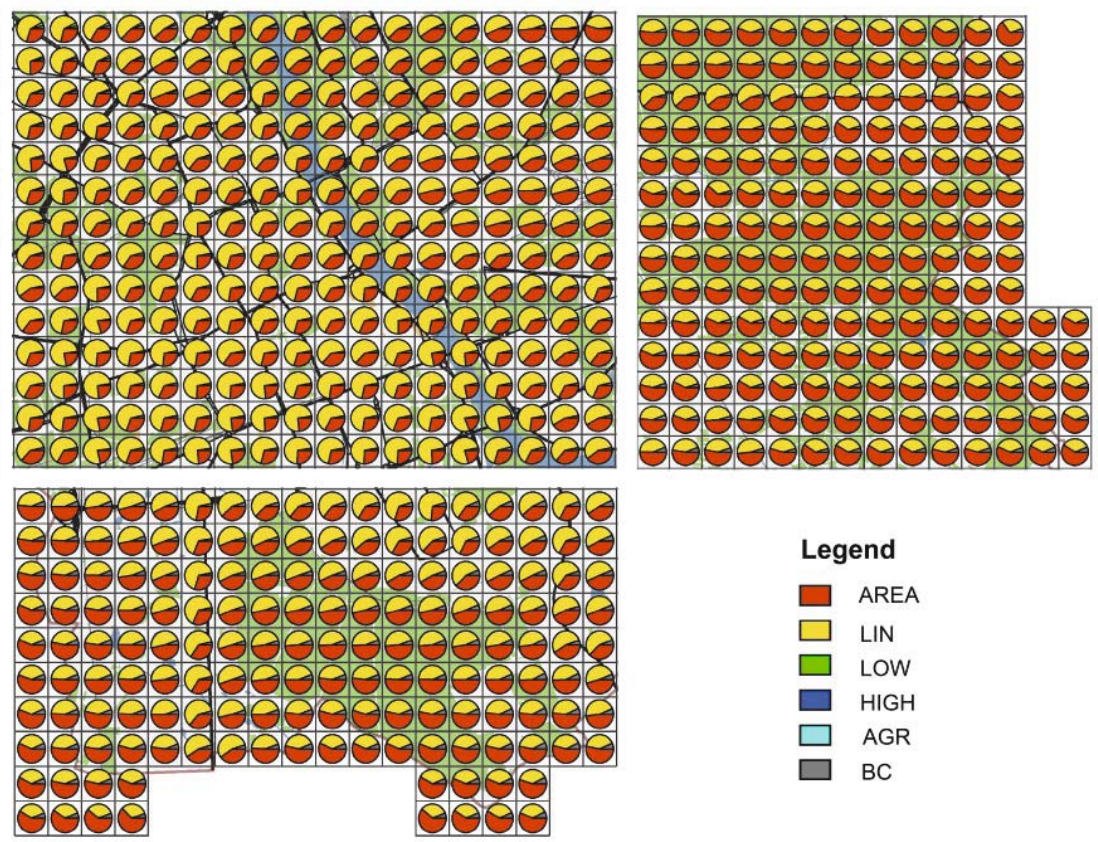
Legend
$\square$ AREA
$\square$ LIN
$\square$ LOW
$\square$ HIGH
$\square$ AGR
$\square$ BC

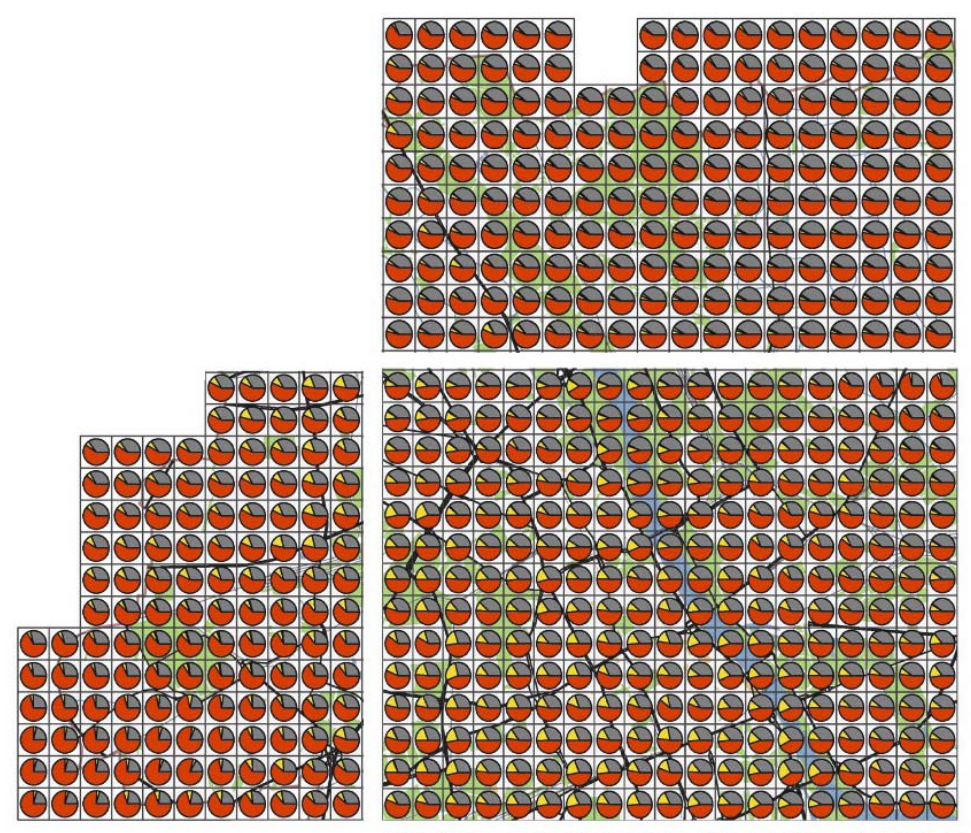

$\mathrm{B}(\mathrm{a}) \mathrm{P}$ - spatial variability of sources's contribution
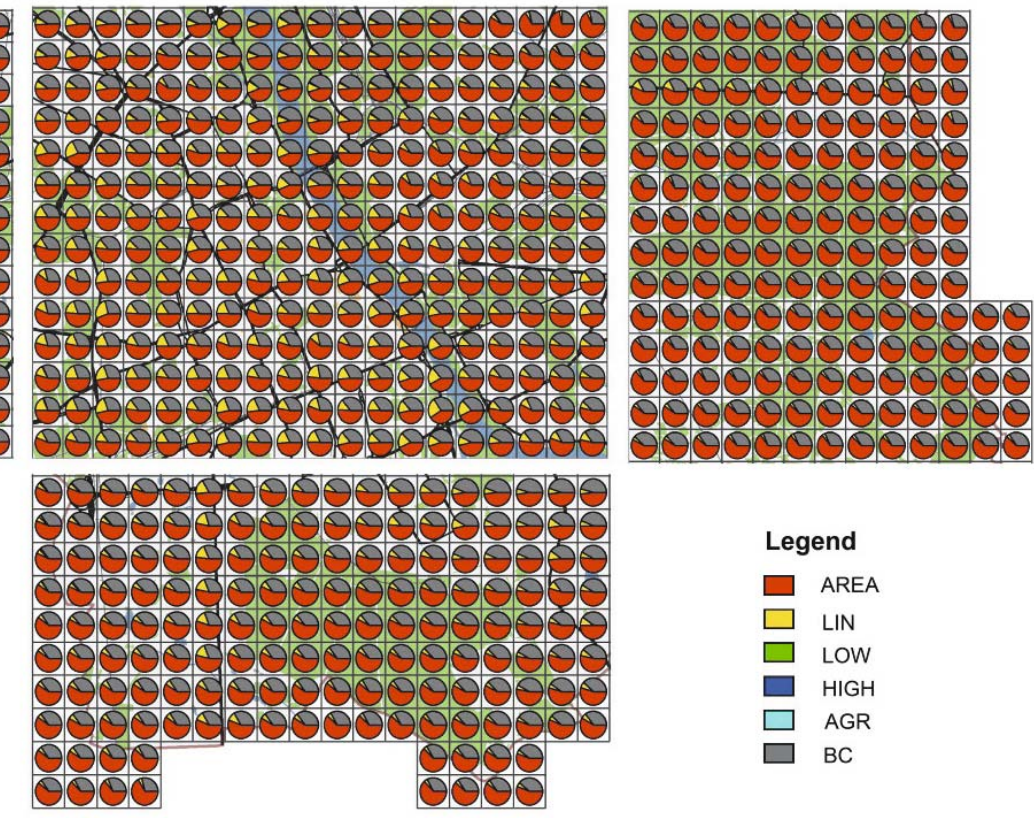

Fig. A3. Spatial variability of the sources contribution for $\mathrm{Pb}$ (top) and $\mathrm{B}(\mathrm{a}) \mathrm{P}$ (bottom) 


\section{Conclusions}

In this study the results of computer analysis of air quality in the Warsaw metropolitan area are presented and discussed. The analysis deals with the main types of urban air pollutants and relies on the real meteorological data and emission field inventory for the year 2012. For computational purposes, the overall emission field has been split down into (see the classification presented in Section 2): (a) high point sources (power and heating plants), (b) other point sources (industry), (c) area sources (residential sector), (d) line sources (urban transport). The impact of the agricultural activity, mainly in the outskirt of Warsaw, is also represented as the area emission field. The regional/national scale transboundary inflow of the main pollutants is taken into account as the boundary conditions for the dispersion model. The main forecasting tool used in the air pollution transport simulations is the regional scale transport modeling system CALMET/CALPUFF (Scire et al. 2000).

The results of this study show the polluting compounds and the regions where some remedial actions are required to eliminate violations of air quality limits. Implementation of such a policy often relies on a cost-effective approach or optimization methods (ApSimon et al. 2002, Carnevale et al. 2012). The uncertainty of the model predictions, which is mainly related to the input data, such as emission inventory or meteorological forecast (Sax and Isakov 2003, Park et al. 2006, Maxim and van der Sluijs 2011) is also an important factor in decision making. Quantifications of emission related uncertainty discussed in Holnicki and Nahorski (2015) show that high uncertainty values were associated with the cases of strongly dominating contribution of one individual source or one category of emission sources. Within this study such domination occurs in the central zone for $\mathrm{NO}_{\mathrm{x}}$ (domination of line sources), or in peripheral districts for $\mathrm{B}(\mathrm{a}) \mathrm{P}$ and $\mathrm{PM}_{2.5}$ (domination of area sources). When faced with a high uncertainty, the emission abatement actions should be greater than that resulting directly from the dominating emission values (see e.g. Hryniewicz et al. 2014), to achieve a higher probability of obtaining the required concentration reductions.

The results presented in Section 3 show that the violations of the air quality standards are mainly due to both fractions of particulate matters, nitrogen oxides, and benzo(a)pyrene. The main source of high $\mathrm{NO}_{\mathrm{x}}$ and $\mathrm{PM}_{10}$ concentrations, and the related adverse environmental impact, is emission from the mobile sources. The contribution of the traffic intensity to $\mathrm{PM}_{10}$ pollution takes place via re-suspended particulates and mainly affects the central district and arterial streets. The problem has intensified due to the steadily increasing number of car journeys (including transit traffic) observed in Warsaw during the last years. Several actions have been taken or are under discussion to address this problem. They include construction of new ring roads, modernization of the public transport (the introduction of the hybrid and electric buses), creation of the network of Park\&Ride places connected to the public transport network. Moreover, the discussion continues about creating the exclusion zone for the motor traffic in the city center.

The Air Quality Management Plan is much more complicated in the case of $\mathrm{B}(\mathrm{a}) \mathrm{P}$ and fine particulates $\mathrm{PM}_{2.5}$, because the problem has not only local but rather a regional character, and any local action cannot be fully effective in this case. To improve the situation, a complex modernization strategy of the coal fired heating installations in detached family houses, particularly those in the surrounding belt of Warsaw is necessary and must be implemented. The projects proposed by the Polish Ministry of Environment include: (i) the subsidized modernization of the heating boiler installations, (ii) stopping the supply of the worst quality coal commonly used for heating purpose, (iii) promoting low-emission fuels which are economically efficient (e.g. gas instead of coal). These actions first of all relate to $\mathrm{B}(\mathrm{a}) \mathrm{P}$ pollution, as violations of the limit values are very high in this case. The above actions will also be effective in the reduction of $\mathrm{PM}_{10}$ and, first of all, $\mathrm{PM}_{2.5}$ concentrations, where limit overruns are less drastic. The share of these compounds in urban air pollution is increasing and the fine dust fractions have strong adverse health effects. When taking into account also the cost of emission abatement, the multicriterial character of the air quality plans is clearly visible. It requires application of computer multicriteria optimization for achieving effective abatement scenarios.

\section{Acknowledgements}

The results have been partially developed in connection with the APPRAISAL project (Air Pollution Policies for Assessment of Integrated Strategies At regional and Local scales), FP7 - ENV2012.6.5-4.

\section{References}

ApSimon, H.M., Warren, R.F. \& Kayin, S. (2002). Addressing uncertainty in environmental modeling: a case study of integrated assessment of strategies to combat long-range transboundary air pollution, Atmospheric Environment, 36, pp. 5417-5426.

Berkowicz, R., Winther, M. \& Ketzel, M. (2006). Traffic pollution modelling and emission data, Environmental Modelling \& Software, 21, pp. 454-460.

Brode, W.R. (2012). CALPUFF Near-field validation. 10th Conference on Air Quality Modeling. Research Triangle Park, NC, March 13, 012 (//epa.gov/scram001/10thmodconfpres.htm(04.11.2016)).

Buchholz, S., Krein, A., Junk, J., Heinemann, G. \& Hoffmann, L. (2013). Simulation of urban-scale air pollution patterns in Luxembourg: contributing sources and emission scenarios, Environmental Modelling \& Assessment, 18, pp. 271-283.

CAFE (2008). Directive 2008/50/EC of the European Parliament and of the Council of 21 May 2008 on ambient air quality and cleaner air for Europe.

Calori, G., Clemente, M., De Maria, R., Finardi, S., Lollobrigida, F. \& Tinarelli, G. (2006). Air quality integrated modelling in Turin urban area, Environmental Modelling \& Software, 21, pp. 468-476.

Carnevale, C., Finzi, G., Pisoni, E., Volta, M., Guariso, G., Gianfreda, R., Maffeis, G., Thunis, P. White, L. \& Triacchini, G. (2012). An integrated assessment tool to define effective air quality policies at regional scale, Environmental Modelling \& Software, 38, pp. 306-315.

Chafe, Z.A., Braue,r M., Klimont, Z., van Dingenen, R., Mehta, S., Rao, S., Riahi K., Dentener, F. \& Smith, K.R. (2014). Household cooking with solid fuels contributes to ambient $\mathrm{PM}_{25}$ air pollution and the burden of disease, Environmental Health Perspectives \& Software, 122, pp. 1-30.

Dernwent, D., Fraser, A., Abott, J., Jenkin, M., Willis, P. \& Murrells, T. (2010). Evaluating the Performance of Air Quality Models, No 3, June 2010. (http://naei.defra.gov.uk/reports?report_ $\mathrm{id}=616(04.11 .2016))$.

Dimitriou, K. \& Kassomenos, P. (2014). A study on the reconstitution of daily $\mathrm{PM}_{10}$ and $\mathrm{PM}_{2.5}$ levels in Paris, Atmospheric Environment, 98, pp. 648-654. 
Dresser, A.L. \& Huizer, R.D. (2011). CALPUFF and AERMOD model validation study in the near field: Martins Creek revisited, Journal of the Air \& Waste Management Association, 61, pp. 641-657.

EEA (2012). European Environment Agency. Air quality in Europe - Report No 4/ 2012.

EEA (2014). European Union emission inventory report 1990-2012 under the UNECE Convention on Long-range Transboundary Air Pollution (LRTAP). EEA Technical report No 12/2014.

Elbir, T. (2003). Comparison of model predictions with the data of an urban air quality monitoring network in Izmir, Turkey, Atmospheric Environment, 37, pp. 2149-2157.

EMEP/EEA (2013). Air pollutant emission inventory guidebook 2013.

ETC/ACM (2013). Technical Paper 2013/11 (R. Rouil, B. Bessagnet, eds). How to start with PM modelling for air quality assessment and planning relevant to AQD.

Holmes, N.S. \& Morawska, L. (2006). A review of dispersion modelling and its application to the dispersion of particles: An overview of different dispersion models available, Atmospheric Environment, 40, pp. 5902-5928.

Holnicki, P. \& Nahorski, Z. (2013). Air quality modeling in Warsaw Metropolitan Area, Journal of Theoretical and Applied Computer Science, 7, pp. 56-69.

Holnicki, P. \& Nahorski Z. (2015). Emission data uncertainty in urban air quality modeling - case study, Environmental Modeling and Assessment, 20, pp. 583-597.

Holnicki, P., Kałuszko, A. \& Trapp, W. (2016). An urban scale application and validation of the CALPUFF model, Atmospheric Pollution Research, 7, pp. 393-402.

Hryniewicz, O., Nahorski, Z., Verstraete, J., Horabik, J. \& Jonas, M. (2014). Compliance for uncertain inventories via probabilistic/fuzzy comparison of alternatives, Climatic Change, 124, pp. 519-534.

Huber, A., Georgopulos, P., Giliam, R., Stenchikov, G., Wang, S., Kelly, B. \& Feingersh, H. (2004). Modeling air pollution from the collapse of the World Trade Center and assessing the potential impacts on human exposures, EM, February 2004, pp. 35-40.

Juda-Rezler, K. (2010). New challenges in air quality and climate modeling, Archives of Environmental Protection, 36, pp. 3-28.

Kiesewetter, G., Borken-Kleefeld, J., Schöpp, W., Heyes, C., Thunis, P., Bessagnet, B., Terrenoire, E. \& Amann, M. (2014). Modelling street level $\mathrm{PM}_{10}$ concentrations across Europe: source apportionment and possible futures, Atmospheric Chemistry and Physics Discussions, 14, pp. 18315-18354.

Lim, L.L., Hughes, S.J. \& Hellawell, E.E. (2005). Integrated decision support system for urban air quality assessment, Environmental Modelling \& Software, 20, pp. 947-954.

Maxim, L. \& van der Sluijs J. (2011). Quality in environmental science for policy: Assessing uncertainty as a component of policy analysis, Environmental Science \& Policy, 14, pp. 482-492.

Mediavilla-Sahagún, A. \& ApSimon, H.M. (2006). Urban scale integrated assessment for London: Which emission reduction strategies are more effective in attaining prescribed $\mathrm{PM}_{10}$ air quality standards by 2005? Environmental Modelling \& Software, 21, pp. 501-513.
ME (2012). Ministry of the Environment. Decree 1031, 24 Aug. 2012, On the admissible levels of some substances in the air. (in Polish)

NCAR (2008). A description of the advanced research WRF Version 3. NCAR Technical Note, TN-475+STR. Boulder, Colorado, USA June 2008.

Oshan, R., Kumar, A. \& Anand, M. (2006). Application of the USEPA's CALPUFF model to an urban area, Environmental Progress \& Sustainable Energy, 25, pp. 12-17.

Oxley, T., Valiantis, M., Elshkaki, A. \& ApSimon, H.M. (2009). Background, Road and Urban Transport modeling of Air quality Limit values (The BRUTAL model), Environmental Modelling \& Software, 24, pp. 1036-1050.

Park, S.-K., Cobb, C.E., Wade, K., Mulholland, J., Hu Y. \& Russel, A.G. (2006). Uncertainty in air quality model evaluation for particulate matter due to spatial variations in pollutant concentrations, Atmospheric Environment, 40, pp. S563-S573.

Patton, A.P., Perkins, J., Zamore, W., Levy, J.I., Brugge, D. \& Durant, J.L. (2014). Spatial and temporal differences in traffic-related air pollution in three urban neighborhoods near an interstate highway, Atmospheric Environment, 99, pp. 309-321.

Pisoni, E., Carnevale, C. \& Volta, M. (2010). Sensitivity to spatial resolution of modeling systems designing air quality control policies, Environmental Modelling \& Software, 25, pp. 66-73.

Rogula-Kozłowska, W., Kozielska, B., Klejnowski, K. \& Szopa, S. (2013). Hazardous compounds in urban PM in the central part of Upper Silesia (Poland) in Winter, Archives of Environmental Protection, 39, pp. 53-65.

Rzeszutek, M. \& Bogacki, M. (2016). The evaluation of the air pollution dispersion model (OSPM): case study, Poland, Kraków, Rocznik Ochrona Środowiska, 18, pp. 351-362. (in Polish)

Sax, T. \& Isakov, V. (2003). A case study for assessing uncertainty in local-scale regulatory air quality modeling applications, Atmospheric Environment, 37, pp. 3481-3489.

Scire, J.S., Strimaitis, D.G. \& Yamartino, R.J. (2000). A User's Guide for the CALPUFF Dispersion Model. Earth Technology Inc.

Tartakovsky, D., Broday, D. M. \& Stern, E. (2013). Evaluation of AERMOD and CALPUFF for predicting ambient concentrations of total suspended particulate matter (TSP) emissions from a quarry in complex terrain, Environmental Pollution, 179, pp. 138-145.

Thunis, P., Rouil, L., Cuvelier, R., Stern, R., Kerschbaumer, A., Bessagnet, B., Schaap, M., Builtjes, P., Tarrason, L., Douros, J., Moussiopoulos, N., Pirovano, G \& Bedogni, M. (2007). Analysis of model responses to emission-reduction scenarios within the CityDelta project, Atmospheric Environment, 41, pp. 208-220.

Trapp, W. (2010). The application of CALMET/CALPUFF models in air quality assessment system in Poland, Archives of Environmental Protection, 36, pp. 63-79.

Villasenor, R., Lopez-Villegas, M. T., Eidels-Dubovoi, S., Quintanar, A. \& Gallardo, J.C. (2003). A mesoscale modeling study of windblown dust on the Mexico City Basin, Atmospheric Environment, 37 , pp. 2451-2462.

WIOŚ (2012). Environment Quality in Mazovian Voivodship in the year 2012. Voivodship Inspectorate of Environment Protection (WIOŚ). Report for the year 2012 (in Polish).

\section{Zanieczyszczenie powietrza w skali miejskiej - analiza jakości powietrza w Warszawie w roku 2012}

Streszczenie: W pracy przedstawiono wyniki analizy jakości powietrza w Warszawie. Obliczenia przeprowadzono dla danych emisyjnych i meteorologicznych z roku 2012. Jako narzędzie modelowania wykorzystano regionalny system CALMET/CALPUFF, którego zadaniem było powiązanie danych emisyjnych z rozkładami stężeń średniorocznych. Analiza dotyczy podstawowych zanieczyszczeń atmosferycznych, charakteryzujących aglomeracje miejskie, jak np.: $\mathrm{PM}_{10}, \mathrm{PM}_{2.5}$, NOx, $\mathrm{SO}_{2}, \mathrm{~Pb}, \mathrm{~B}(\mathrm{a}) \mathrm{P}$, metale ciężkie. Celem analizy było zidentyfikowanie 
najbardziej zanieczyszczonych obszarów miasta oraz zanieczyszczeń, których stężenia przekraczają poziomy dopuszczalne. Ponadto, wskazanie źródeł emisji (lub kategorii emisyjnych), które głównie odpowiadają za te przekroczenia, powodując negatywne skutki zdrowotne. Wyniki modelowania pokazują, w jakim stopniu główne źródła emisyjne - związane z sektorami energii, przemysłu, transportu lub komunalno-bytowym - odpowiadają za wartości stężeń w receptorach. Uwzględniono przy tym udział transgranicznego napływu zanieczyszczeń. Wyniki pozwalają wskazać dzielnice, w których zostały przekroczone poziomy dopuszczalne stężeń i konieczne są odpowiednie działania naprawcze. Dokonano ilościowej oceny udziału źródeł emisji głównie odpowiedzialnych za przekroczenia standardów. Ruch uliczny oraz sektor komunalno-bytowy wskazano jako kategorie emisyjne, które mają decydujący wpływ na pogarszanie jakości powietrza w Warszawie. W przypadku niektórych zanieczyszczeń (np. PM) bardzo istotny jest również udział napływu zewnętrznego. Wyniki mogą być przydatne przy wyborze strategii ograniczania emisji oraz jako część zintegrowanego systemu modelowania. 